HOOFDSTUK II

\title{
Indonesië en de Verenigde Oost-Indische Compagnie
}

\section{Inleiding en overzicht}

De bijzondere betrekkingen tussen Indonesië en Nederland hebben hun ontstaan te danken gehad aan de wens van Nederlandse kooplieden op het eind van de zestiende eeuw om de lucratieve specerijenhandel aan zich te trekken. Zij wilden de specerijen die toen nog alleen door Portugal werden aangevoerd voortaan zelf in de productiegebieden aanschaffen en stuurden daartoe tientallen bewapende schepen om Afrika heen naar Zuidoost-Azië. In 1602 voegden zij hun ondernemingen samen tot één nieuwe maatschappij, de 'Verenigde Oost-Indische Compagnie' (VOC). De Nederlandse republiek, die zelf pas kort voordien tot stand gekomen was, machtigde deze Compagnie tot het uitoefenen van overheidsfuncties.

De VOC maakte al snel een eind aan Portugal's heerschappij in de Molukken, onder meer door verovering van het Portugese fort op Ambon. Later verdreef zij de Portugezen ook uit Malakka, Ceylon en een deel van India. Zij opende een groot aantal handelsposten binnen en buiten de Indonesische archipel. Zij verwoestte de havenstad Djakarta op Java en stichtte daar een eigen hoofdkwartier, Batavia, dat uitgroeide tot het belangrijkste handelscentrum van Zuidoost-Azië.

Ter verkrijging van zo veel mogelijk winst uit de specerijenhandel spande de VOC zich in om alle concurrentie uit te schakelen. Daarbij keerde zij zich niet alleen tegen haar Europese rivalen, maar gebruikte zij ook geweld om de inheemse bevolking te dwingen uitsluitend aan haar te leveren. Overigens hield de Compagnie zich met veel meer dan alleen specerijenhandel bezig. Zij ging ook een grote rol spelen in het handelsverkeer tussen de Aziatische landen onderling. Haar keten van handelsposten strekte zich uit van Arabië tot Japan. Naar Europa exporteerde zij vooral specerijen en textiel en later ook koffie en thee. Zij beschikte in Azië over een strak georganiseerd ambtenarenapparaat onder leiding van een gouverneur-generaal.

De VOC was geen staat, maar trad wel op als een staat. Zij oefende bestuur 
en rechtspraak uit, nam krijgsvolk in dienst, liet forten bouwen en sloot verdragen met Aziatische vorsten. Hoewel zij was opgericht om handel te drijven en niet om land te veroveren, kwam toch in de loop van de zeventiende en achttiende eeuw steeds meer Aziatisch grondgebied onder haar heerschappij. Dit was niet alleen het gevolg van oorlog met handelsrivalen maar ook van conflicten tussen Aziaten onderling. Vooral binnen de Indonesische archipel werd de VOC omringd door staten die elkaars vijanden waren of zelf door interne twisten werden verscheurd; dit stelde haar in staat hier een overheersende positie te verwerven. Al in de zeventiende eeuw werd zowel Mataram als Bantam daardoor aan haar onderhorig. Omdat steeds meer gebied onder heerschappij van de VOC kwam te staan, moest een deel van haar ambtenaren zich meer met bestuur dan met handel bezighouden. Daar kwam bij dat de Compagnie ook een actieve rol ging spelen in de productie van sommige handelsgoederen, zoals koffie. Aldus werd de VOC behalve een maritieme macht ook een territoriale macht; tegelijk werd zij naast een handelsonderneming ook een landbouwonderneming.

De VOC heeft bijna twee eeuwen bestaan. Op het eind van de achttiende eeuw had zij het oppergezag over heel Java en de Molukken en bezat zij verscheidene steunpunten in de rest van de archipel, maar als handelsonderneming maakte zij het slecht. Haar organisatie leed onder verstarring en corruptie. Van Groot-Brittannië en Frankrijk ondervond zij sterke concurrentie. Haar uitgaven waren sterk gestegen, haar inkomsten daalden, zij raakte in de schuld en vroeg de Nederlandse overheid om financiële steun. Uiteindelijk besloot deze de VOC met ingang van het jaar 1800 op te heffen. Al haar bezittingen en schulden gingen toen over op de Nederlandse staat.

\section{De geboorte van de Nederlandse staat}

De ontdekkingsreizen van Portugezen en Spanjaarden in verre werelddelen en de daar door hen verworven rijkdommen prikkelden andere zeevarende Europese volkeren tot navolging. In de loop van de zestiende eeuw waagden eerst Fransen, vervolgens Britten en tenslotte ook Nederlanders zich aan soortgelijke ondernemingen. Dat Nederlanders hier pas laat in de eeuw aan begonnen kwam niet door gebrek aan maritieme ervaring. De als 'Nederlanden' bekend staande gewesten (waarvan het grondgebied ruwweg overeenkwam met dat van het huidige Nederland en België en een stuk van Noord-Frankrijk) beheersten al in het begin van de eeuw het leeuwendeel van het handelsverkeer over zee in een gebied dat zich uitstrekte van Scandinavië en de Oostzeelanden tot Portugal en Spanje. Gezamenlijk beschikten ze over de grootste handelsvloot van West-Europa. Anders echter dan Frankrijk en Engeland waren de Nederlanden geen zelfstandige staat maar een groep 
afzonderlijke gewesten, die pas in de eerste helft van de zestiende eeuw volledig onder één gezag kwamen te staan. Door vererving werd dit het gezag van de koning van Spanje. In 1568 begon prins Willem van Oranje, bijgenaamd 'Willem de Zwijger', een gewapende opstand tegen het Spaanse bestuur, die een tachtigjarige oorlog tegen vreemde overheersing inluidde.

Het verloop van de strijd leidde tot een splitsing van het gebied, doordat het Spaanse gezag zich wel in de zuidelijke gewesten wist te handhaven of te herstellen maar uiteindelijk niet in de noordelijke. Deze laatste gewesten gingen sinds 1588 verder als een onafhankelijke republiek, de 'Verenigde Nederlanden'. In deze nieuwe staat, die van 1594 af uit zeven provincies bestond, had men een voorkeur voor collegiaal bestuur. Elke provincie werd bestuurd door een college, de 'Staten', en de Republiek als geheel werd eveneens door een college bestuurd, de 'Staten-Generaal'. Wel beschikten de provincies meestal over een aan de Staten ondergeschikte gouverneur, de 'stadhouder'. Bovendien werd de Republiek in de praktijk gedomineerd door Holland, de grootste en rijkste provincie, en volgden de Staten-Generaal in de eerste decennia meestal de leiding van Johan van Oldenbarnevelt, voorzitter van de delegatie van Holland.

\section{De eerste Nederlandse tochten naar Azië}

Het verloop van de opstand tegen Spanje leidde er ook toe, dat Antwerpen zijn toegang tot zee verloor, dat Amsterdam nu het belangrijkste handelscentrum werd en dat ervaren en kapitaalkrachtige handelaren uit de zuidelijke gewesten zich in de provincies Holland en Zeeland vestigden. Daar stimuleerden zij onder meer de ontluikende belangstelling voor het openen van eigen handelswegen naar Azië.

Deze belangstelling gold in de eerste plaats de specerijenhandel. De Aziatische specerijen die de Portugezen in Lissabon aanvoerden werden al jarenlang grotendeels door Nederlandse kooplieden verder verhandeld. De Nederlandse handel zou natuurlijk veel meer kunnen verdienen als men die specerijen rechtstreeks uit Azië zou invoeren. Daar kwam bij dat, sinds Portugal zelf onder gezag van de Spaanse koning was komen te staan, de Portugese havens herhaaldelijk gesloten werden voor schepen uit de opstandige Nederlandse gewesten.

In de jonge Republiek werd stelselmatig kennis vergaard over Azië en de scheepvaartroutes daarheen. Belangrijke bijdragen daartoe leverde Jan Huyghen van Linschoten, een Hollander die vijf jaar in Goa gewerkt had en in 1592 in Nederland terugkeerde. Hij bezat niet alleen een schat van gegevens over de Aziatische landen, maar kende ook de zwakheden van de Portugese positie in Azië en in het bijzonder in de Indonesische archipel. Een 


\title{
IT IN E R A R I O.

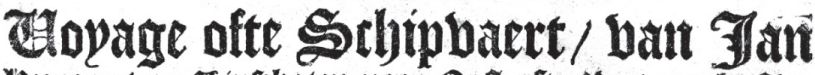 Hivgen ban 2 intehoten naet Boft ofte

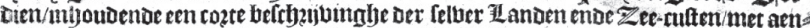

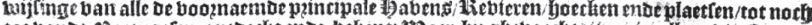

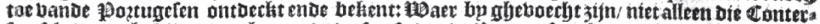

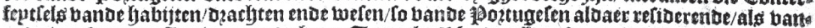

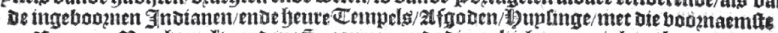

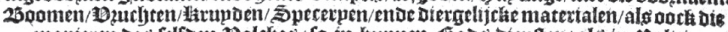

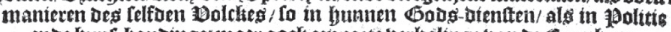 choe fupf-hondinge: macr oodf ee cozte berf alinge ban de Coophans Delingen/ foe ende waex ofe glyedecen ende gftebonoen woz:

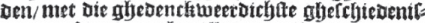

$$
\text { fem/ boozglyeballen oen tijt jijn }
$$ \\ oer refioentie aldaer.
}

Alles befchreven ende by een vergadert, door den felfden, feer nut, oorbaer, ende oock vermakelijcken voor alle curieufe ende Liefhebbers van vreemdigheden.

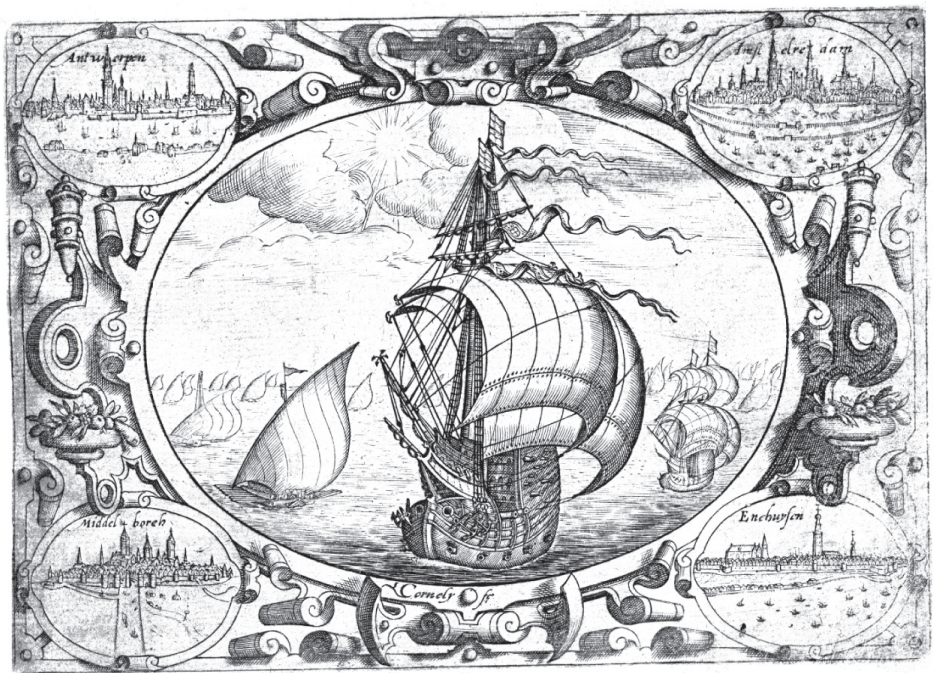

\author{
t'A M T E L R E D A M, \\ By Cornelis Clae z.op't VVater int Schrïfboeck, by de oude Brugghe.
}

Het in 1595-96 in druk verschenen Itinerario bevatte in negenennegentig hoofdstukken een schat van gegevens over Azië, verzameld door Jan Huygen van Linschoten (1563-1611), een Nederlander die grote reizen had gemaakt en onder meer vijf jaar had gewoond in Goa, de voornaamste Portugese vestiging in India. 
en ander legde hij neer in zijn boek Itinerario, voyage ofte schipvaert naer Oost ofte Portugaels Indien.

Van Linschoten behoorde overigens tot degenen die aanvankelijk geloofden dat de kortste weg van Nederland naar 'Indië' om het noorden van Europa en Azië liep. Men had geen vermoeden van de uitgestrektheid van Siberië en dacht dat de Aziatische kust voorbij Noord-Rusland meteen naar China afboog. Van Linschoten nam zelf in 1594 en 1595 deel aan expedities die vruchteloos probeerden deze 'noordoostelijke doorvaart' te vinden. Een derde expeditie, in 1596 vertrokken onder leiding van Willem Barentsz en Jacob van Heemskerk, liep uit op een onvrijwillige overwintering op Nova Zembla. Daarna gaf men deze pogingen op.

De route naar 'Indië' om Afrika heen bleek toch de beste te zijn. Ten tijde van de overwintering op Nova Zembla had de eerste Nederlandse expeditie langs deze 'zuidoostelijke doorvaart' haar bestemming al bereikt. Die expeditie was georganiseerd door enige Amsterdamse kooplieden die daartoe een maatschappij hadden opgericht, de Compagnie van Verre. Zij rustten een vloot van vier schepen uit die in april 1595 vertrok, met 249 opvarenden onder leiding van Cornelis de Houtman. Omdat de Portugezen de Straat van Malakka beheersten zou men via Straat Soenda naar Java en de Molukken gaan. Het werd een rampzalige tocht.

De heenreis duurde ruim een half jaar langer dan verwacht en kostte het leven aan de helft van de schepelingen, vooral ten gevolge van scheurbuik. Pas eind juni 1596 kwam de vloot aan op de rede van Bantam; daar werd zij begroet door Portugese handelaren die in Bantam waren om peper in te kopen. De vloot bleef enige maanden op de rede liggen in afwachting van de nieuwe peperoogst. De Bantamse bestuurders ontvingen De Houtman welwillend. Hij voerde onderhandelingen met hen (in het Portugees), sloot een Nederlands-Bantams vriendschapsverdrag en sprak af dat zijn schepen bij voorrang bevoorraad zouden worden. Maar in september ontstond hierover hooglopende ruzie. De Houtman dreigde de stad te laten beschieten; de Bantammers namen hem en zijn gevolg daarop gevangen. De bemanning van de schepen loste inderdaad kanonschoten op de stad, sloeg een aanval van Bantamse oorlogsscheepjes af en maakte zich meester van de lading van enkele Portugese boten, maar moest uiteindelijk een hoog losgeld betalen om De Houtman en de zijnen vrij te krijgen.

Hierna vertrok de Nederlandse vloot oostwaarts. Zij deed de haven van Djakarta aan, maar werd verder tot geen enkele Javaanse haven meer toegelaten. Bij Soerabaja verloor men twaalf man door een aanval van zeerovers; bij Madoera doodde men uit paniek de plaatselijke vorst die ter begroeting kwam aanvaren. Pas op Bali kregen de Nederlanders een warm onthaal. Hier bleven zij enige tijd om zich op de terugreis voor te bereiden; van het voorgenomen bezoek aan de Molukken zagen zij af. In augustus 1597 keerde het 
restant van de expeditie, nog maar 89 man, met drie schepen in Nederland terug. Twee bemanningsleden waren op Bali gedeserteerd; zij waren de eerste Nederlanders die zich in Indonesië vestigden.

Het fiasco van deze eerste tocht ontmoedigde de Nederlandse kooplieden allerminst. In verschillende Hollandse en Zeeuwse steden richtten zij compagnieën op voor de handel met Azië. Al in 1598 vertrokken vijf nieuwe eskaders met in totaal tweeëntwintig schepen daarheen. De belangrijkste vloot werd weer uitgezonden door de Amsterdamse Compagnie van Verre en bestond uit acht schepen onder leiding van Jacob van Neck. In zeven maanden voer deze vloot naar Bantam. Daar bleek men de Nederlanders weer gunstig gezind te zijn; dit was het averechtse gevolg van een strafexpeditie die de Portugezen kort daarvoor tegen Bantam hadden ondernomen. Van Neck kon hier goede zaken doen; nadat de helft van zijn vloot vol geladen was, keerde hij daarmee naar Nederland terug. De andere vier schepen voeren door naar de Molukken. Ook hier werden de Nederlanders hartelijk verwelkomd omdat ze als bondgenoten tegen de Portugezen werden gezien. Ze bezochten Ambon, Banda en Ternate, deden grote aankopen van specerijen en richtten enkele handelsposten in. Binnen twee jaar na vertrek waren alle acht schepen weer in Nederland terug. De Amsterdamse compagnie boekte 400\% winst.

Van de andere in 1598 ondernomen expedities had slechts één een matig succes en liepen drie uit op een mislukking. Eén van die drie was een Zeeuwse expeditie onder leiding van Cornelis de Houtman naar Atjeh, destijds na Bantam het belangrijkste Indonesische handelscentrum. Pas na vijftien maanden kwamen de Zeeuwse schepen daar aan. De sultan ontving de Nederlanders eerst vriendelijk maar keerde zich later tegen hen. Cornelis de Houtman vond de dood bij een aanval op zijn schepen; zijn broer Frederik werd gevangen genomen. De schepen konden ontkomen en naar Zeeland terugkeren, maar Frederik de Houtman bleef twee jaar in Atjeh gevangen. Hij schreef daar het eerste Maleis-Nederlandse woordenboek.

Twee van de in 1598 ondernomen expedities probeerden Azië te bereiken via de 'zuidwestelijke doorvaart', dat wil zeggen langs de zuidpunt van het Amerikaanse continent. Daartoe behoorde een Rotterdamse vloot van vijf schepen, waarvan er slechts één terugkeerde maar dit was niet verder dan Zuid-Amerika gekomen. Een ander schip van deze vloot, genaamd de 'Liefde', strandde in 1600 voor de kust van Japan; het daarop volgende verblijf van de bemanning in dat land vormde het begin van de Nederlands-Japanse betrekkingen. De tweede westwaartse expeditie werd ondernomen door een Amsterdamse vloot van vier schepen onder Olivier van Noort. Ook hiervan keerde er maar één terug, met Van Noort. Zijn schip had Indonesië bereikt en was via de zuidpunt van Afrika naar Nederland gevaren; dit was de eerste Nederlandse reis om de wereld.

Het ongelukkige verloop van sommige van de eerste Nederlandse tochten 
naar Azië heeft zich later niet meer in vergelijkbare mate herhaald. In 1599 vertrokken er drie eskaders naar Indië, in 1600 twee en in 1601 weer drie. In totaal namen hier negenendertig schepen aan deel; ze keerden allemaal behouden terug. Al in deze periode vertrokken er uit Nederland meer schepen naar Azië dan uit Portugal. Die Nederlandse schepen bezochten niet alleen Indonesië maar ook Ceylon, Thailand, Indochina en de Filippijnen.

Op Java en de Molukken hadden de Nederlanders over het algemeen een goede verstandhouding met de Indonesiërs met wie ze te maken kregen. Een Zeeuwse expeditie slaagde er in 1601 in ook het conflict met Atjeh bij te leggen. De sultan, die graag militaire hulp van Nederland tegen de Portugezen wilde hebben, liet Frederik de Houtman vrij en zond met de Zeeuwse retourvloot een gezantschap mee. De Atjehse gezanten verbleven ruim een jaar in Nederland; zij waren de eerste Indonesiërs die dit land bezochten. De bejaarde leider van het gezantschap stierf daar en werd in Middelburg begraven.

\section{Oprichting van de Verenigde Oost-Indische Compagnie}

Hoewel de Nederlandse tochten naar Azië particuliere ondernemingen waren, hielden ook de Nederlandse overheden zich er van begin af aan mee bezig, onder meer wegens de oorlog met Spanje. De Staten van de betrokken provincies stelden geschut en munitie beschikbaar en voorzagen de leiders van de expedities van instructies. Ook prins Maurits, zoon van Willem de Zwijger en stadhouder in vijf provincies, instrueerde de vertrekkende vloten en gaf brieven mee voor Aziatische staatshoofden; in Indonesië werd hij door de Nederlandse kooplieden vaak als monarch voorgesteld. De Staten-Generaal bemoeiden zich zowel met de militaire en politieke als met de economische aspecten van de vaart op Azië. Al in 1598 deden zij een dringend beroep op de verschillende Hollandse en Zeeuwse compagnieën om elkaar niet tegen te werken. Maar ook zonder opzettelijke tegenwerking was het onvermijdelijk dat de concurrentie tussen de compagnieën de handelswinst niet ten goede kwam. De in Indonesië te betalen inkoopprijzen en havenrechten vlogen met sprongen omhoog; de verkoopprijzen op de Europese markt zakten flink onder de prijzen die de Portugezen plachten te rekenen. Bovendien bemoeilijkte het gescheiden opereren van de Nederlandse compagnieën het bieden van doeltreffende tegenweer tegen de toenemende Portugees-Spaanse inspanningen om met militair geweld de Portugese positie in de Indonesische archipel te herstellen.

Johan van Oldenbarnevelt vond dat men zo niet door kon gaan. Met hulp van prins Maurits overreedde hij alle compagnieën (inmiddels gevestigd in Amsterdam, Delft, Enkhuizen, Hoorn, Middelburg en Rotterdam) om samen te gaan in één nieuwe maatschappij. Aldus kwam op 20 maart 1602 de 
'Generale Vereenichde Geoctroyeerde Oost-Indische Compagnie' tot stand, beter bekend onder de naam 'Verenigde Oost-Indische Compagnie' (VOC). Met 'Oost-Indië' bedoelde men destijds het hele gebied tussen Arabië en Perzië enerzijds en China en Japan anderzijds, terwijl de term 'West-Indië' op Amerika betrekking had.

Deze VOC was een hoogst merkwaardige instelling: een particuliere maatschappij op aandelen die niettemin gerechtigd was belangrijke overheidsfuncties uit te oefenen. De Staten-Generaal verleenden haar een uitgebreid octrooi. Daarin kreeg de VOC in de eerste plaats het alleenrecht om handel te drijven in het deel van de wereld gelegen ten oosten van Kaap de Goede Hoop en ten westen van Straat Magelhaes. Tegelijk kreeg zij het recht om daar namens de Staten-Generaal verdragen te sluiten met plaatselijke autoriteiten, om forten en versterkingen te bouwen, om krijgsvolk in dienst te nemen en om bestuur en rechtspraak uit te oefenen. Het aan de VOC verleende handelsmonopolie bond de Nederlandse onderdanen, maar kon natuurlijk geen anderen binden, noch in Europa noch in Azië. Het octrooi werd in eerste aanleg verleend voor een periode van 21 jaar; het is daarna telkens voor bepaalde tijdvakken verlengd, tot aan het einde van de achttiende eeuw.

Aan het hoofd van de VOC stond een college van zeventien bestuurders, gewoonlijk de Heren Zeventien genoemd. Pas in 1609 werd ook voorzien in een hieraan ondergeschikt centraal bewind in Azië, bestaande uit een gouverneur-generaal en enige andere belangrijke Compagniesdienaren, die tezamen de Raad van Indië vormden. Dit bewind werd niet in de eerste plaats ingesteld om gebied te besturen, maar om leiding te geven aan handelsactiviteiten. Het oppergezag berustte bij de gouverneur-generaal, maar in overeenstemming met de toen in Nederland heersende afkeer van eenhoofdig bestuur mocht hij de meeste van zijn bevoegdheden alleen met instemming van de meerderheid van de Raad uitoefenen. De eerste gouverneur-generaal was Pieter Both.

Einde van de Portugese heerschappij in de Molukken; vestiging van de VOC op Ambon

Op het eind van de zestiende eeuw lag op Zuid-Ambon de voornaamste Portugese basis ten oosten van Malakka. In maart 1599 werd het eiland voor het eerst door Nederlandse schepen bezocht, behorende tot de vloot van Jacob van Neck. Hun ondercommandant was Jacob van Heemskerk, die twee jaar eerder nog op Nova Zembla overwinterde. De bevolking van Hitoe, het noordelijk deel van Ambon, hoopte op Nederlandse hulp om de Portugezen te verjagen, maar de Nederlanders waren alleen gekomen om handel te drijven.

Een jaar later arriveerde een ander Nederlands eskader, onder Steven van der Hagen die wel bereid was militaire hulp te verlenen. Daarop kwam in 1600 
een formeel bondgenootschap tussen Nederland en Ambon tot stand, maar het lukte Van der Hagen niet het sterke Portugese fort te veroveren.

Portugal besloot nu tot drastische actie om een eind te maken aan de Nederlandse opmars in de Indonesische archipel. Daartoe vertrok eind 1601 een vloot van dertig oorlogsschepen uit Malakka. Eerst blokkeerden de Portugezen de haven van Bantam, maar zij hieven deze blokkade op nadat ze waren aangevallen door een juist uit Nederland aankomend eskader van vijf schepen, dat enkele Portugese schepen tot zinken bracht. Deze overwinning voor de kust van Bantam kwam het Nederlandse prestige op Java zeer ten goede. De Portugezen voeren nu door naar Ambon, waar zij in Hitoe grote verwoestingen aanrichtten als straf voor het bondgenootschap met Nederland. Vervolgens probeerden zij Ternate te onderwerpen, maar daarvoor bleken zij niet sterk genoeg. Zwaar gehavend keerde de vloot naar Malakka terug.

Door deze mislukte expeditie werd de Portugese positie in de Molukken zowel militair als politiek ernstig verzwakt. Eind 1604 zonden de leiders van Hitoe een dringend hulpverzoek aan Van der Hagen die wederom met een vloot uit Nederland in Bantam was aangekomen, nu onder de vlag van de VOC. Van der Hagen voer daarop naar Ambon voor een nieuwe poging om het Portugese fort te veroveren. Ditmaal capituleerde het fort terstond. De Nederlanders namen het in bezit en doopten het Victoria. Korte tijd later veroverden zij ook de Portugese vesting op Tidore. Dit betekende het einde van de Portugese heerschappij in de Molukken.

Het eiland Ambon werd in februari 1605 in feite de eerste Nederlandse kolonie overzee. De VOC beschouwde het van Portugal overgenomen ZuidAmbon als eigen grondgebied krachtens het 'recht van verovering'. Bovendien sloten de hoofden van Hitoe na de Portugese capitulatie een nieuw verdrag met de VOC, waarin ze eeuwige trouw aan Nederland en de Compagnie beloofden. In hetzelfde verdrag verplichtten ze zich zonder Nederlands verlof geen kruidnagelen aan anderen dan Nederlanders te leveren. Terwijl het verdrag van 1600 nog op basis van gelijkheid gesloten was, werd Hitoe door het 'Eeuwig Verbond' van 1605 in feite een vazal van Nederland.

Door een en ander kwam de VOC op Ambon in een nieuwe positie te verkeren. In alle andere plaatsen waar zij vestigingen had, zoals Bantam, Djakarta en Ternate, was zij ondergeschikt aan het plaatselijk gezag; op Ambon was zij baas in eigen huis.

De Compagnie vestigde haar hoofdkwartier in het fort Victoria. Frederik de Houtman, die met Van der Hagen meegekomen was, werd gouverneur van Ambon. In de dorpen nabij het fort woonden destijds ongeveer zestienduizend katholieke Ambonezen, die nu vrijwel allen tot het protestantisme overgingen. Voor hen vertaalde De Houtman verschillende christelijke teksten in het Maleis. Doordat de VOC haar basis aan de zuidzijde van de baai vestigde, verschoof daarheen het politieke en commerciële zwaartepunt van 
Ambon. Uit de VOC-basis ontstond de huidige hoofdplaats van het eiland, Kota Ambon.

De Compagnie maakte op Ambon al spoedig gebruik van haar bevoegdheid om krijgsvolk in dienst te nemen. Zowel christelijke als islamitische Ambonezen wierf zij als soldaten aan.

\section{Britse concurrentie}

In de tweede helft van de zestiende eeuw was de Indonesische archipel enige malen door Britse zeevaarders bezocht, maar die hadden daar toen nog geen handelsbetrekkingen aangeknoopt. Pas nadat de Nederlandse tochten waren begonnen, begaven ook Britse kooplieden zich in de handel met 'Indië'. Eind 1600 verenigden zij zich daartoe in een Company of Merchants of London Trading to the East Indies beter bekend onder de naam East India Company (EIC). Deze compagnie kreeg monopolierechten van de Britse kroon, maar viel verder meer te vergelijken met de Amsterdamse Compagnie van Verre. $\mathrm{Zij}$ beschikte niet over publiekrechtelijke bevoegdheden zoals in 1602 aan de VOC werden verleend (zulke bevoegdheden verkreeg zij pas tegen het eind van de zeventiende eeuw, onder uitdrukkelijke verwijzing naar het Nederlandse voorbeeld). Haar kapitaal was oorspronkelijk slechts een achtste van dat van de VOC.

Hoewel de EIC veel minder schepen inzette dan de VOC, wist zij al spoedig in Indonesië verscheidene handelsposten in te richten, vrijwel steeds op plaatsen waar de VOC zulke posten al bezat. Dit Britse optreden wekte veel ergernis bij de Nederlanders. Dezen vonden dat de Britten kosteloos profiteerden van de strijd die zij zelf tegen de Portugezen hadden gevoerd. Nog erger was dat de Britse concurrentie precies die handelsvoordelen teniet dreigde te doen waarvoor de VOC als monopoliemaatschappij in het leven was geroepen. Juist dit laatste leidde soms tot gewapende conflicten met de Britten, onder andere op de Banda-eilanden.

De koning van Groot-Brittannië protesteerde keer op keer bij de StatenGeneraal tegen de inbreuken van de VOC op de Britse vrijheid van handel. In 1613 en 1615 vonden hierover Brits-Nederlandse besprekingen plaats, waarbij Hugo de Groot de opstelling van de VOC verdedigde. De Nederlanders bleven onverminderd vasthouden aan hun monopolieposities in de Molukken. Tenslotte zond de Britse regering in 1618 een vloot naar Azië om kracht bij te zetten aan haar aanspraken op vrijheid van handel in de Indonesische archipel. 


\section{Spraeckende woord-boeck, Jnoe ftalevlebe ende fladagalkat=

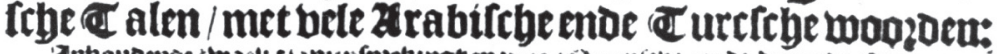

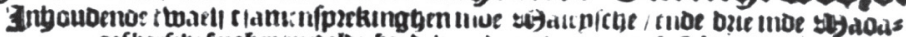

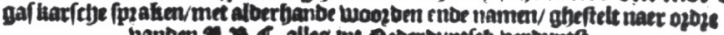

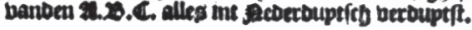

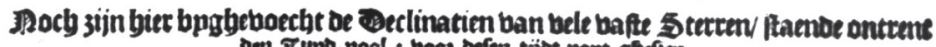 Den Zupo-pool : boos befen tijot nopt ghrfien. \\ Sonderling nut voor de ghene die de Landen van Ooft-Indien befoecken:ende niet min vermakelick voor alle curieufe Lief-hebbers van vreemdicheydr. Alles gheftelde, gheobferveert, ende befchreven door \\ Frederick de Howtman van Gonda.}

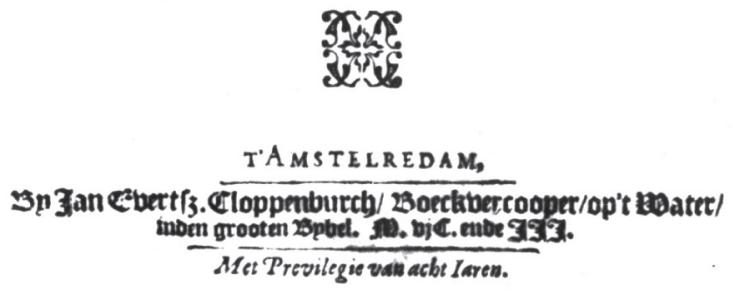

Dit eerste Nederlandse woorden- en leerboek van de Maleise taal werd in 1603 gepubliceerd door Frederik de Houtman (1571-1627), die had deelgenomen aan de eerste Nederlandse reizen naar Indonesië, maar daar van 1599 tot 1601 gevangen was gehouden door de sultan van Atjeh en toen de taal grondig had bestudeerd. 


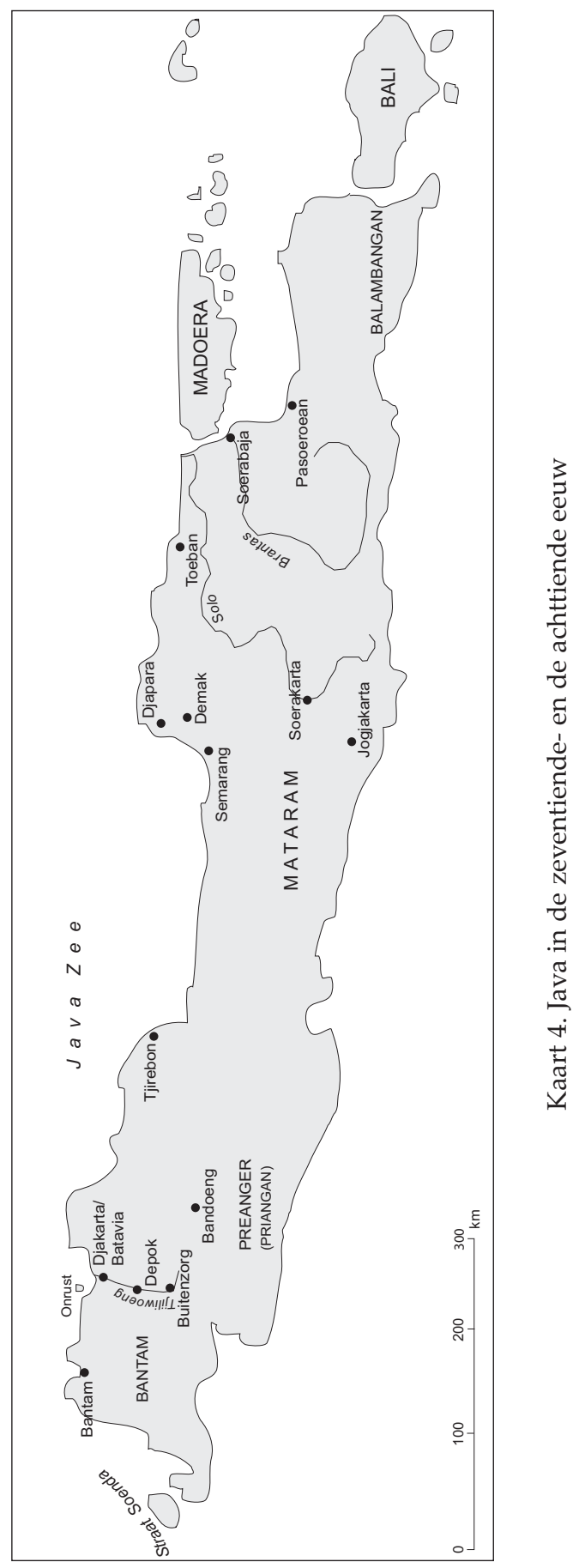




\section{Nederlaag van de Britten; stichting van Batavia}

Al binnen tien jaar na de oprichting van de Verenigde Oost-Indische Compagnie ging haar arbeidsveld veel meer omvatten dan alleen de Molukken. Niet alleen beschikte zij al over verscheidene vestigingen op Java en Sumatra, maar ook had zij tussen 1605 en 1610 al vier handelsposten aan de kust van India ingericht. Bovendien opende zij in 1609 een post in Japan. De Heren Zeventien vonden het daarom wenselijk binnen dit arbeidsveld een centraal steunpunt in te richten, dat zij aanduidden als 'rendez-vous'. Zij wilden de in Azië verworven handelswaren daar centraal laten opslaan en vandaar naar Nederland laten verschepen. Ook zou de gouverneur-generaal daar zijn kantoor moeten hebben. Het ging dus in feite om de hoofdzetel van de Compagnie in Azië.

Het VOC-bestuur vond Ambon te ver oostelijk gelegen om als centraal rendez-vous te dienen en zocht daarom naar een plaats in de nabijheid van Straat Soenda. Hoewel Bantam hier het dichtst bij lag, wilde de VOC haar hoofdzetel daar niet vestigen omdat zij dan geheel van de sultan en zijn regering afhankelijk zou zijn. Daarom ging haar voorkeur uit naar het kleinere Djakarta, dat wel aan Bantam onderhorig was maar aan de rand van het Bantamse gebied lag op de westelijke oever van de Tjiliwoeng. De eerste drie gouverneurs-generaal kwamen niet aan de oprichting van een nieuw hoofdkwartier toe en verbleven meestal in de Molukken. Wel werd het commerciële hoofdkantoor van de VOC in Bantam gevestigd en werd de centrale boekhouding uit Ambon daarheen overgebracht. Pas de vierde gouverneur-generaal, Jan Pieterszoon Coen, stichtte het beoogde definitieve hoofdkwartier.

Coen was in 1613 op 26-jarige leeftijd aangesteld als directeur van de VOCkantoren in Bantam en Djakarta. De plaatselijke bestuurder van Djakarta had de Compagnie toegestaan daar op de oostelijke oever een handelspost met pakhuizen in te richten onder de strikte voorwaarde dat er geen fort zou worden gebouwd. In strijd hiermee liet Coen de pakhuizen in het geheim toch versterken. In $1618 \mathrm{kreeg}$ hij bericht van de Heren Zeventien dat hij tot gouverneur-generaal benoemd was met ingang van de dag waarop zijn voorganger, Laurens Reael, hem in die functie zou beëdigen. Vooreerst had hij echter geen gelegenheid om voor zijn beëdiging naar Ambon te gaan. Hij had een conflict met de regering van Bantam, terwijl tegelijkertijd de Britse houding steeds dreigender werd. Coen nam zijn intrek in de VOC-post in Djakarta en liet het complex nu openlijk tot een fort versterken. De bestuurder van Djakarta protesteerde hiertegen en verbood de bevolking voor de Nederlanders te werken. Inmiddels hadden de Britten een handelspost gevestigd aan de westkant van de Tjiliwoeng tegenover de VOC-post. Coen, die een aanval van de Britse vloot verwachtte, liet eind december de Britse post verwoesten, nadat daar geschut was opgesteld dat op het Nederlandse complex gericht was. Daarop begonnen de Djakartanen met Britse hulp een belegering 
van het Nederlandse fort. Enkele dagen later naderde een Britse vloot van elf schepen. De Nederlanders beschikten bij Djakarta slechts over zeven schepen en weinig munitie; hun hoofdmacht lag in de Molukken. Na enige gevechten met de Britse vloot besloot Coen op 3 januari 1619 met zijn schepen naar de Molukken uit te wijken. Hij droeg de bezetting van het fort op zich zo lang mogelijk te verdedigen.

Voortdurende onderlinge onenigheid tussen de Djakartanen, de Britten en de Bantammers werd de redding van het belegerde fort. Na een maand van onderhandelen besloten de Nederlanders zich over te geven aan hun belegeraars, maar op de dag dat de overgave zou plaatsvinden kwam de regering van Bantam tussenbeide. $\mathrm{Zij}$ zette de bestuurder van Djakarta af en eiste dat het fort aan haar zou worden overgegeven. De Britten vertrokken en de Bantammers namen zowel de belegering als de onderhandelingen over.

Deze toestand duurde nog voort toen Coen, inmiddels als gouverneurgeneraal geïnstalleerd, op 28 mei met een vloot van zeventien schepen uit de Molukken aankwam. Nadat het krijgsvolk aan land was gebracht viel Coen op 30 mei met duizend man Djakarta aan, dat hier volstrekt niet op voorbereid was. De Bantamse krijgslieden sloegen op de vlucht. De verovering van de plaats kostte de Nederlanders één dag en één dode. De bevolking van Djakarta en omstreken werd volledig verdreven; het stadje werd in zijn geheel verbrand en gesloopt.

Hierna voer Coen naar Bantam en eiste vrijlating van het inmiddels gevangen genomen VOC-personeel. De Bantamse regering liet de Nederlanders vrij maar verbood de Compagnie verder nog in Bantam handel te drijven. Coen antwoordde hierop met een blokkade van de haven van Bantam. Vervolgens gingen eskaders van de Nederlandse vloot jacht maken op de Britse schepen, waarvan zij er in enkele maanden zeven uitschakelden. De andere Britse schepen trokken zich terug naar India. Zo verloor Groot-Brittannië de strijd om de oppermacht ter zee in de Indonesische archipel.

De verovering van Djakarta stelde de VOC in staat haar centrale hoofdkwartier op eigen grondgebied te vestigen. Coen claimde zelfs dat de territoriale soevereiniteitsrechten van de Compagnie zich uitstrekten tot de zuidkust van Java. Hij liet als hoofdkwartier een nieuwe en grotere versterking bouwen. Ten zuiden en ten westen daarvan verrees een nieuwe stad, met kanalen en bruggen in Nederlandse trant. Op aanwijzing van het Nederlandse VOCbestuur ging de stad Batavia heten, naar een toen in de mode zijnde Latijnse naam voor Nederland.

De blokkade van Bantam, die tot 1628 is voortgezet, stelde Batavia in staat nu zelf het belangrijkste handelscentrum van de archipel te worden. Daar kwam bij dat sultan Agoeng van Mataram in diezelfde periode een eind maakte aan het bestaan van alle andere Noord-Javaanse handelsstaatjes. Deze Mataramse veroveringen werden in 1625 afgerond door de val van Soerabaja. 
De stad Batavia kreeg een gevarieerde bevolking. De grootste groep naast de Nederlanders werd gevormd door de Chinezen, van wie zich in 1620 al achthonderd in de stad gevestigd hadden. Daarnaast waren er onder meer Maleise handelaren, Ambonese en Japanse huursoldaten en Balinese slaven, maar lange tijd vrijwel geen Javanen of Soendanezen. De algemene omgangstaal in de stad was niet het Nederlands maar het Portugees, dat later werd verdrongen door het Maleis.

Omdat de oorspronkelijke bevolking in de wijde omtrek verdreven was, werd Batavia aan de landzijde omringd door een verwilderd niemandsland, waar hoge Compagniesdienaren soms gingen jagen op tijgers en neushoorns.

Coen ging in 1623 naar Nederland, maar keerde vier jaar later terug voor een tweede termijn als gouverneur-generaal. Sultan Agoeng van Mataram probeerde in 1628 en opnieuw in 1629 Batavia te veroveren, maar ondanks inzet van een enorme troepenmacht was hij beide keren gedwongen het beleg op te breken. Hierna is de stad niet meer aangevallen. Coen stierf in 1629 tijdens het tweede Mataramse beleg.

\section{De doelstellingen van de VOC}

De Portugezen en de Spanjaarden waren de wereld ingetrokken 'om te veroveren en te bekeren', ook al wilden ze tegelijkertijd rijkdommen verwerven. De pioniers van de Spaanse kolonisatie heten dan ook de 'conquistadores'. Daarentegen was de VOC een organisatie van kooplieden. Tegenover de onder haar gezag komende Aziatische gebieden gedroeg zij zich daarom anders dan Portugal en Spanje tegenover hun koloniën. Zij stelde weinig belang in migratie van Nederlandse onderdanen naar die gebieden en zij spande zich niet in om daar de Nederlandse taal ingang te doen vinden bij de inheemse bevolking noch om die bevolking tot het christendom te bekeren. Alleen op Ambon en later op Ceylon sloot haar bestuur nauwer aan bij het Portugese model, vooral onder invloed van de inheemse christenen die onder het vorige bewind de status van Portugese onderdanen hadden genoten. Verder kregen de Bandaeilanden een geheel afwijkende behandeling.

Het handelsbeleid van de VOC berustte op drie beginselen: goedkoop inkopen, duur verkopen en concurrentie tegengaan. Het haar door de StatenGeneraal verleende handelsmonopolie beschermde haar tegen Nederlandse concurrentie. Buitenlandse concurrentie probeerde zij in de eerste plaats te weren door ook van Aziatische gezagsdragers en leveranciers monopolies te verkrijgen, vooral in de vorm van exclusieve inkooprechten. Daarnaast was zij bereid geweld te gebruiken, hetzij om Europese concurrenten te verdrijven hetzij om Aziaten te dwingen de monopoliecontracten na te leven.

Binnen de VOC vond in de eerste decennia veel discussie plaats over het te 
voeren beleid. Jan Pieterszoon Coen had daar vastomlijnde denkbeelden over die hij in tal van geschriften aan de Heren Zeventien voorlegde. Hem stond de schepping voor ogen van een groot Aziatisch handelsrijk. De Nederlanders, die zich al als de vrachtvaarders van Europa beschouwden, zouden ook de vrachtvaarders van Azië moeten worden. Van Perzië tot Japan zouden zij een overheersende positie dienen in te nemen in het overzeese handelsverkeer tussen de Aziatische landen onderling. Daarmee zouden zij grote winsten kunnen maken omdat, zo betoogde Coen, die landen de Europese landen in bevolking, in verbruik van goederen en in industrie overtroffen. Uit de met die handel te behalen winsten zou men niet alleen de apparaatskosten van de VOC kunnen betalen maar ook de aankoop van de naar Europa uit te voeren specerijen.

Om dit handelsrijk te scheppen en te handhaven achtte Coen sterke militaire middelen nodig. Al in 1613 pleitte hij voor verovering van Macao en Manila om de Portugezen en Spanjaarden van de Chinese kust en uit de Filippijnen te verdrijven. Telkens weer drong hij aan op versterking van de Nederlandse vloot in de Aziatische wateren. Aan Nederlandse soldaten had hij minder behoefte. Zijns inziens zou de VOC het grootste deel van haar krijgsvolk in Azië zelf kunnen aanwerven. In het bijzonder dacht hij aan het recruteren van Japanse huursoldaten.

Coen pleitte niet voor het verwerven van omvangrijke territoriale bezittingen. Het zou voor de VOC voldoende zijn hier en daar over steunpunten in de vorm van eigen grondgebied te beschikken. In die gebieden zouden Nederlanders zich als kolonisten moeten vestigen. Aan deze kolonisten wilde Coen een deel van de Aziatische handel overlaten, onder toezicht van de Compagnie. Ook zouden zij de specerijenproductie moeten overnemen, met de hulp van slaven naar het voorbeeld van de slavenarbeid op de plantages in Amerika. Ter versterking van de kolonisten in de Nederlandse steunpunten wilde Coen arbeidskrachten goedschiks of kwaadschiks aanvoeren uit China, Achter-Indië en Madagaskar. De eigen bevolking van Indonesië speelde in Coen's plannen nauwelijks een rol.

Uiteindelijk heeft het VOC-bestuur de denkbeelden van Coen maar ten dele gevolgd. Voor offensieve operaties in de door hem bepleite omvang voelde het weinig. De mislukking van een door Coen in 1622 ondernomen poging om Macao te veroveren vormde ook geen aanmoediging om op deze lijn door te gaan. Evenmin is er veel terecht gekomen van Coen's plannen voor de vestiging van Nederlandse kolonisten. Het VOC-bestuur was trouwens volstrekt niet bereid om aan particuliere Nederlandse burgers toe te staan in Azië handel te drijven.

Daarentegen onderschreef de VOC het belang van een zo groot mogelijk aandeel in de handel tussen de Aziatische landen onderling. Zoals uit Coen's betoog al blijkt, zag men de Aziatische landen destijds niet als achterlijk maar 
als ontwikkeld, ook al waren de Europeanen maritiem en militair superieur gebleken. Het ontwikkelingspeil van die landen bracht ook mee dat de import van specerijen, zijde, porselein en andere kostbaarheden uit Azië niet voldoende kon worden bekostigd door de export van Europese goederen, aangezien Europa nauwelijks goederen te bieden had die aantrekkelijk waren voor de Aziatische markt. Daarom betaalden de Europese kooplieden de Aziatische goederen vooral met zilver, dat toen in Azië een hogere ruilwaarde had dan in Europa.

Terwijl de VOC de Aziatische handel nodig had om haar eigen kosten te dekken, verwachtte zij haar winsten in de eerste plaats van de specerijenimport in Europa. Daarbij wilde zij, in elk geval wat de Molukse specerijen betrof, een volstrekt monopolie hebben om de prijzen in Europa hoog te kunnen houden. De discussies binnen de VOC betroffen vooral de vraag hoe men zich van zulk een monopolie zou moeten verzekeren. De voorstanders van de zachte lijn (onder wie Laurens Reael en ook Steven van der Hagen, die in 1617 gouverneur van Ambon werd) wilden dit monopolie langs vrijwillige weg bewerkstelligen op basis van een goede verstandhouding met de inheemse bevolking. De voorstanders van de harde lijn, zoals Coen, vonden gebruik van geweld onmisbaar om het monopolie te handhaven; daarbij zou men onder meer een eind moeten maken aan het inheemse scheepvaart- en handelsverkeer.

Hoewel de VOC-leiding soms kritiek had op het brute optreden van Coen, koos zij in feite voor de harde lijn. Een consequentie daarvan was dat zij zich niet alleen met de handel maar ook met de productie van de specerijen ging bemoeien. Overigens ging zij daarbij niet over tot het door Coen bepleite stelsel van productie in eigen beheer met volledige uitschakeling van de inheemse productie, behalve op de Banda-eilanden waar Coen dit beleid al ten uitvoer had gebracht.

\section{Ontvolking van de Banda-eilanden}

Muskaatbomen leveren twee specerijen op die destijds in Europa bijzonder gezocht waren: muskaatnoot en foelie. Deze bomen groeiden vroeger uitsluitend in de Zuid-Molukken, voornamelijk op de kleine bergachtige Bandaeilanden. In de zestiende eeuw probeerden de Portugezen vergeefs zich hier een monopoliepositie te verschaffen. In 1599 werd de eilandengroep bezocht door Nederlandse schepen onder Jacob van Heemskerk, die er een handelspost vestigde. Vervolgens verwierf de VOC in de eerste jaren van haar bestaan op verschillende Banda-eilanden exclusieve rechten op de levering van muskaatnoot.

De zo goed begonnen verstandhouding tussen Nederlanders en Bandanezen verslechterde al spoedig. De eersten stonden op hun exclusieve rechten, maar 
de laatsten bleven aan andere afnemers leveren. In 1609 stuurde de VOC een expeditie naar de Banda-eilanden om haar monopolie af te dwingen. Daartoe wilde zij er forten vestigen, in de eerste plaats op Neira, het eiland met de voornaamste ankerplaats. De bevolking was daar tegen en doodde de Nederlandse commandant en zijn gevolg. De Nederlanders moordden uit wraak enige dorpen uit, namen Neira in bezit en bouwden er het fort Nassau.

Enige jaren later vestigde ook de East India Company een handelspost op de Banda-eilanden. De VOC bleef in conflicten gewikkeld, zowel met de Bandanezen als met de Britten, over haar monopolie-aanspraken. Zij placht de te leveren specerijen van te voren te betalen en was bijzonder gegriefd wanneer die vervolgens toch aan anderen verkocht werden. De Heren Zeventien adviseerden, de voornaamste Bandanezen 'uit te roeien' als straf voor hun voortdurende contractbreuk, maar gouverneur-generaal Laurens Reael was daartoe niet bereid.

Coen, die als jong VOC-ambtenaar al had deelgenomen aan de expeditie van 1609, voer als gouverneur-generaal in 1621 met een grote strijdmacht naar de Banda-eilanden. De Bandanezen boden onderhandelingen aan, maar Coen wees die af. Hij wilde de door het VOC-bestuur aangegeven definitieve oplossing van het Banda-probleem doorvoeren, namelijk de eilanden volledig veroveren en van een nieuwe bevolking voorzien. De verovering nam maanden in beslag wegens hardnekkig verzet van de Bandanezen. Coen liet hun kustdorpen en vaartuigen in brand steken om vluchten te beletten. Van de ruim vijftienduizend eilandbewoners overleefden nog geen duizend het Nederlandse optreden. Velen sneuvelden in de strijd. Ruim veertig vooraanstaande personen werden van verraad beschuldigd, gemarteld en door Japanse soldaten geëxecuteerd. Van de bevolking die zich in de bergen verschanst had, werd een deel door de VOC-soldaten gedood en stierf de rest de hongerdood. Een paar honderd anderen slaagden er in naar het eiland Ceram te vluchten. De ongeveer zevenhonderdenvijftig Bandanezen die zich hadden overgegeven werden weggevoerd naar Batavia; een vijfde deel daarvan overleefde het transport niet.

De VOC beschouwde de Banda-eilanden voortaan als eigen grondgebied krachtens het recht van verovering. Naar het vrijwel geheel ontvolkte gebied bracht zij nieuwe bewoners over van zeer uiteenlopende herkomst, voornamelijk gewezen dienaren en soldaten van de Compagnie. Die kregen slaven tot hun beschikking, die de Compagnie onder meer op Bali gekocht had en waarmee zij voortaan de muskaatbomen moesten verzorgen. De aldus gewonnen specerijen mochten alleen aan de VOC worden geleverd. Alle muskaatbomen die buiten de Banda-eilanden groeiden, voornamelijk op Ambon, werden door de VOC uitgeroeid.

Toen Coen's optreden tegen de Bandanezen in Nederland bekend werd wekte dit veel kritiek, waarbij zowel politieke als morele argumenten wer- 
den aangevoerd. Sommigen noemden het onverstandig om de Nederlandse positie in Azië in hoofdzaak te baseren op het aanstichten van vrees. Anderen merkten op dat de Bandanezen voor hun vrijheid gevochten hadden zoals de Nederlanders tegen de Spanjaarden.

\section{Onderwerping van de Molukken}

Kruidnagelbomen groeiden oorspronkelijk alleen in de Noord-Molukken, maar werden in de loop van de zestiende eeuw ook in de Zuid-Molukken aangeplant. Het heeft de VOC ruim een halve eeuw gekost om zich volledig van het kruidnagelmonopolie te verzekeren. Daartoe moest zij de oppermacht over de Molukse bevolking verwerven en bovendien haar Europese concurrenten uitschakelen: de Portugezen, de Spanjaarden en de Britten.

De macht van Portugal in de Molukken werd al in 1605 gebroken, toen het zijn steunpunten op Ambon en Tidore verloor; handel bedreef het daarna nog alleen vanuit Makassar. In plaats van Portugal verwierf Spanje nu een machtspositie in het gebied. Het trok in 1606 uit de Filippijnen de Molukken binnen en dwong Ternate en Tidore om Spaanse forten op hun grondgebied te dulden. Maar wat voor de Nederlanders in militair opzicht een tegenslag was bleek hun in politiek opzicht winst op te leveren. De vijandschap met Spanje bracht de sultan van Ternate al in 1607 ertoe een verdrag met Nederland te sluiten waarin hij de Republiek als zijn beschermer erkende. Bovendien mocht de VOC ook een fort op Ternate bouwen (het fort Oranje) en kreeg zij een exclusief recht op de aankoop van kruidnagelen.

De Britten werden in 1619 uit de Indonesische archipel verdreven, maar keerden er een jaar later op bescheiden schaal weer terug, nadat de twee moedercompagnieën in Europa een verdrag van vrede en samenwerking hadden gesloten. Zo opende de EIC handelsposten onder meer in Batavia en op Ambon. Aan haar samenwerking met de VOC kwam echter al in 1623 een eind na een incident dat in de Britse geschiedschrijving is blijven voortleven als de 'Amboyna massacre'. Een tiental Britten op Ambon werd verdacht van een complot tegen de VOC, gemarteld en vervolgens veroordeeld en terechtgesteld. De EIC trok zich daarop grotendeels uit Indonesië terug. De VOC verbood alle buitenlandse scheepvaart in de Molukse wateren.

De voornaamste strijd om het kruidnagelmonopolie heeft de VOC met de bevolking van de Molukken zelf gevoerd. Dat Indonesische vorsten en besturen aan de Compagnie monopolierechten verleenden was op zichzelf niet iets nieuws. Ook voor de komst van de Nederlanders waren zulke rechten vaak verleend, onder meer aan de Portugezen, maar ze waren zelden strikt toegepast. Het nieuwe van de VOC was dat zij de haar verleende monopolies streng naar de letter uitlegde en dat zij bereid was geweld te gebruiken om 
ze te handhaven. Door voorschotten te verlenen maakte zij haar leveranciers tot schuldenaren. Tegelijkertijd stelde zij eenzijdig lage inkoopprijzen voor de specerijen vast. De bevolking leed nadeel van het verbod om specerijen aan anderen te verkopen, niet alleen omdat die bereid waren meer te betalen dan de VOC maar ook omdat de Molukkers de verkoop binnen de Indonesische archipel nodig hadden ten behoeve van hun eigen invoer, vooral die van rijst. Weliswaar nam de VOC op zich om zelf voor de invoer van rijst en andere benodigdheden te zorgen, maar daarvoor rekende zij hogere prijzen dan die op de vrije markt.

Intussen was de VOC niet in staat om met haar zeemacht een eind te maken aan de inheemse kruidnageluitvoer uit de Molukken. Weliswaar verbood zij de bevolking om buiten de Molukse wateren te varen, maar zij kon in dit uitgestrekte gebied nu eenmaal niet met enkele tientallen grote schepen al het verkeer van honderden kleine bootjes controleren. Daarom greep zij naar een ander middel: vernietiging van de kruidnagelbomen op alle eilanden die niet direct onder haar toezicht stonden, een bijzonder effectief middel omdat deze bomen pas na twaalf jaar vrucht beginnen te dragen. Men begon hiermee in 1625 door het verbranden van vijfendertigduizend kruidnagelbomen op het eiland Ceram.

Het Nederlandse optreden tastte de bevolking van de Molukken aan in haar twee voornaamste middelen van bestaan: de specerijenteelt en de vrije scheepvaart. Dit leidde tot een reeks opstanden die met korte onderbrekingen van 1635 tot 1656 hebben geduurd en waarbij van beide kanten wreed is opgetreden. De eerste opstanden braken uit op Ambon en werden langdurig in de Zuid--Molukse berggebieden voortgezet. De grootste opstand begon in 1650 gelijktijdig op Ambon en Ternate en breidde zich over het hele gebied van de Molukken uit. Pas na zes jaar slaagde de VOC er in deze opstand volledig te onderdrukken.

Als reactie op de Ambonse opstanden beëindigde de VOC de formele onderhorigheid van Hitoe aan Ternate en bracht zij heel Ambon onder haar rechtstreeks bestuur. De kruidnagelteelt werd beperkt tot dit eiland en drie nabij gelegen eilandjes. Daarmee verminderde de VOC de kruidnagelproductie tot een kwart van de vroegere omvang. De sultans van Ternate en Tidore kregen een jaargeld als compensatie voor de afschaffing van de kruidnagelteelt in hun gebieden. Ter handhaving van het VOC-monopolie werden jaarlijkse controle-expedities uitgevoerd, de hongi-tochten. De gouverneur van Ambon maakte dan, begeleid door een vloot van inheemse schepen, een tocht langs alle eilanden, waarbij ontdekte clandestiene vruchtbomen werden omgehakt en de bij inbreuken op het monopolie betrokken bevolking werd gestraft, onder meer door het platbranden van dorpen. Door dit alles verviel het eens zo bloeiende gebied van de Molukken tot armoede en apathie, terwille van de handelswinsten van de VOC. 
De liquidatie van de specerijenteelt buiten de door de VOC daarvoor aangewezen gebieden was voor de Spanjaarden aanleiding de Molukken te verlaten; in 1663 trokken zij zich terug uit Ternate en Tidore.

In 1675 kwam Ternate nog eenmaal in verzet. Nadat dit verzet was gebroken veranderde de VOC de formele status van het sultanaat: in plaats van een bondgenoot werd het nu een leen van de Compagnie. In 1677 erkende ook Tidore de opperheerschappij van de Compagnie. Hiermee was de onderwerping van de Molukken door de VOC voltooid.

\section{Machtsuitbreiding in India en op Ceylon, Sumatra en Celebes}

Hoewel de Heren Zeventien uit waren op het scheppen van een handelsrijk en niet op het veroveren van land, kwam in de zeventiende eeuw toch steeds meer Aziatisch grondgebied onder de directe of indirecte heerschappij van de Compagnie. Aldus werd de VOC behalve een maritieme macht ook een territoriale macht. In het algemeen waren de VOC-bestuurders in Azië meer tot machtuitbreiding geneigd dan die in Nederland. Zulke machtsuitbreiding kon zowel het resultaat zijn van oorlogen tussen de VOC en haar handelsrivalen als van bemoeienis door de VOC met conflicten tussen Aziaten onderling.

In het bijzonder in de Indonesische archipel bevond de Compagnie zich te midden van staten die elkaars vijanden waren of die zelf door interne twisten werden verscheurd, meestal over opvolgingskwesties. Het kwam herhaaldelijk voor dat één van de partijen bij zulk een conflict steun bij haar zocht. Wanneer de bestuurders in Batavia daar op ingingen, plachten zij bij voorkeur steun te geven aan de zwakste partij. Voor de verleende steun vroegen zij tegenprestaties die zowel op commercieel als op politiek terrein konden liggen. Aldus belandden heel wat Aziatische regeerders in een positie van afhankelijkheid van de Compagnie.

Tussen 1637 en 1663 schakelde de VOC haar oudste rivaal, Portugal, bijna geheel uit. Met hulp van het sultanaat Djohore lukte het haar in 1641 eindelijk Malakka te veroveren. Zij legde een militaire bezetting in deze stad, maar verwaarloosde de handelshaven, want aan een concurrent van Batavia had zij geen behoefte. Enkele jaren daarvoor had de Compagnie zich al meester gemaakt van een deel van de Portugese vestingen op Ceylon. Zij was daartoe aangemoedigd door de koning van Kandy in het binnenland van het eiland. $\mathrm{Na}$ een tienjarige wapenstilstand tussen Nederland en Portugal, dat intussen weer onafhankelijk van Spanje was geworden, hervatte de Republiek in 1652 de oorlog. Op aandrang van de Staten-Generaal viel de VOC opnieuw de Portugese posities in Azië aan. In 1658 verdreef zij de Portugezen volledig uit Ceylon, waardoor zij alle kuststeden in handen kreeg. Voortaan zetelde in Colombo een gouverneur van de VOC, terwijl de koning van Kandy het bin- 
nenland bleef regeren. De Compagnie bezat nu het monopolie op de handel in kaneel, dat alleen op dit eiland gewonnen werd. In dezelfde periode veroverde de VOC bovendien alle Portugese vestingen aan de oostkust van India en verschillende van die aan de westkust.

Intussen vergrootte de VOC ook haar invloed op Sumatra. Daar had Atjeh in de eerste decennia van de zeventiende eeuw het toppunt van zijn macht bereikt onder het bewind van sultan Iskandar Moeda. Zijn gezag strekte zich toen aan de westkant van Sumatra uit tot voorbij het kustgebied van Minangkabau, aan de oostkant tot alle kustgebieden tegenover het schiereiland Malakka en ten noorden van Sumatra tot enige delen van dit schiereiland zelf. Atjeh beheerste daardoor een groot deel van de handel in peper en in tin. Maar de vele door Iskandar Moeda gevoerde oorlogen hadden het land zelf uitgeput en zijn vloot verzwakt. Na de verovering van de stad Malakka zette de VOC, die de peper- en tinhandel naar zich toe wilde trekken, Atjeh steeds meer onder druk. De positie van de Compagnie werd versterkt doordat de vorstendommen Palembang en Djambi zich met haar verbonden en haar monopolierechten gaven. De conflicten met Atjeh leidden de VOC tot enige havenblokkades en tenslotte tot een militaire expeditie, waarmee zij het sultanaat in 1659 tot een vernederend vredesverdrag dwong. Onder meer moest Atjeh voortaan aan de Compagnie het leeuwendeel van de tinhandel overlaten. Enkele jaren later maakten vier vorstendommen aan de westkust zich van Atjeh los en stelden zij zich onder bescherming van de VOC. Deze vestigde in 1667 in Padang haar hoofdkantoor voor Sumatra's westkust, terwijl zij zich bovendien enige invloed in het bergland boven Padang verschafte door een verdrag met de vorst van Minangkabau.

Een gevaarlijker rivaal van de VOC dan Atjeh was Gowa. In Zuid-Celebes woonden twee volken voor wie de scheepvaart een belangrijk middel van bestaan was: de Makassaren en de Boeginezen. De belangrijkste Makassaarse staat was Gowa in het zuidwesten met de havenstad Makassar; de belangrijkste Boeginese staat was Boni in het oosten. Beide staten gingen pas bij het begin van de zeventiende eeuw tot de islam over. Kort daarna werd Gowa een sultanaat en ontwikkelde het zich tot een groot zeerijk; het veroverde niet alleen Boni maar ook andere delen van Celebes en een aantal van de omliggende eilanden. Makassaarse kooplieden namen de rol van de Javaanse handelaren over toen de meeste Javaanse havensteden in verval raakten na te zijn veroverd door Mataram. Daardoor werd Makassar onder het bewind van sultan Hasanoedin de belangrijkste havenstad in de oostelijke helft van de Indonesische archipel. Het werd in het bijzonder het centrum van de handel in Molukse specerijen buiten de VOC om, een handel die de Compagnie als smokkel beschouwde. De Portugezen maakten Makassar tot hun voornaamste handelsbasis in Indonesië; ook Britse en Deense kooplieden vestigden zich daar. 
Gowa en de VOC koersten af op een frontale botsing. Al in het midden van de eeuw voerden ze een paar keer oorlog, maar de Compagnie was toen nog niet aan een echte confrontatie toe, omdat zij haar soldaten nodig had voor het onderdrukken van de opstanden in de Molukken en voor het bestrijden van de Portugezen in India en op Ceylon. Enige jaren later, toen de VOC haar handen weer vrij had, bood een verbannen vorst van Boni, Aroeng Palaka, zich als bondgenoot aan. Daarop begon de VOC in 1666 een grootscheepse oorlog tegen de Makassaren. De leiding berustte bij Cornelis Speelman, die ook beschikte over Ambonese en Ternataanse hulptroepen en samenwerkte met de Boeginese krijgers onder Aroeng Palaka. Het duurde tot 1669 voordat sultan Hasanoedin definitief verslagen was. De VOC bracht Gowa daarop tot kleine omvang terug. Van de vroeger door dit sultanaat veroverde gebieden in en buiten Celebes werden sommige aan Ternate toegewezen als beloning voor de bewezen diensten; de andere werden vazalstaten van de Compagnie, met inbegrip van Boni, dat overigens wel een voorkeursbehandeling kreeg. Veel Makassaren verlieten Gowa en bleven de Nederlanders elders bestrijden, hetzij als zeerovers hetzij als krijgers in dienst van vijanden van de Compagnie. De VOC maakte de stad Makassar tot eigen grondgebied en ontmantelde er de talrijke zware versterkingen, behalve het fort Oedjoeng Pandang, dat werd omgedoopt tot fort Rotterdam. Zij liet in Makassar geen andere Europeanen meer toe dan haar eigen dienaren. Het VOC-monopolie van de Molukse specerijen was voortaan onaantastbaar.

Intussen had de VOC al voor de verovering van Makassar een steunpunt verworven in de noordoosthoek van Celebes, namelijk in Menado waar zij het fort Amsterdam had gebouwd. Zij had zich hier in 1658 gevestigd op verzoek van de plaatselijke bevolking, die Nederlandse bescherming zocht tegen de Ternatanen en de Spanjaarden.

\section{Verwerving van de oppermacht op Java}

Terwijl de VOC nu oppermachtig was in de oostelijke helft van de Indonesische archipel, lag haar hoofdstad Batavia nog steeds ingeklemd tussen het sultanaat Bantam en het rijk Mataram. In 1628, toen Mataram zich tegen Batavia keerde, had de Compagnie snel vrede met Bantam gesloten en de blokkade opgeheven, maar die vrede bleek niet duurzaam. Met Mataram bleef de oorlogstoestand bestaan zolang sultan Agoeng leefde; pas na diens dood in 1645 sloot zijn zoon vrede met de VOC.

De regeerders van Mataram grepen terug op het Javaanse verleden. Zij vervingen de titel van sultan door de titel 'soesoehoenan', tooiden zich niet meer met Arabische maar met Javaanse namen en droegen een kroon van gouddraad die afkomstig heette te zijn van Modjopahit. Ook onderdrukten zij de 
activiteiten van islamitische geestelijke leiders. De VOC behandelde Mataram met respect. Al in 1614 en volgende jaren hadden gezanten van de Compagnie het hof van sultan Agoeng bezocht. Zijn residentie, de kraton, lag ten zuiden van het huidige Jogjakarta. Na de vrede met zijn opvolger zond de VOC weer jaarlijks een gezantschap naar het Mataramse hof.

Het grote rijk Mataram was echter een reus op lemen voeten. Het was door Senopati en sultan Agoeng met geweld bijeengebracht, maar de door hen onderworpen vorstenhuizen schikten zich niet gemakkelijk in hun lot. In 1676 brak een opstand uit onder leiding van de Madoerese prins Troenodjojo, die met hulp van Makassaarse krijgers een deel van Oost-Java veroverde. De meeste kustgewesten liepen naar hem over. Zowel de soesoehoenan als de opstandige prins vroeg nu hulp aan de VOC. De Compagnie besloot de soesoehoenan te steunen en zond een expeditie onder Speelman, die Troenodjojo uit Soerabaja verdreef. Maar de rebel was niet verslagen; integendeel, enkele maanden later veroverde hij de kraton van de soesoehoenan. Deze laatste stierf op de vlucht; hij werd opgevolgd door zijn oudste zoon, die in 1677 een verdrag met Speelman sloot waarin hij grote concessies deed in ruil voor terugkeer op de troon. Onder meer beloofde hij aan de VOC de kosten van haar militaire bijstand te vergoeden en gaf hij haar de stad Semarang als onderpand voor zijn schuld. Ook stond hij het gebied tussen Batavia en het gewest Tjirebon aan de VOC af en verleende hij haar handelsmonopolies.

Om de nieuwe soesoehoenan op de troon van Mataram te plaatsen trok de Compagnie in 1678 met een grote strijdmacht het binnenland van Java in. Ook Aroeng Palaka met zijn Boeginezen nam daaraan weer deel. Na zware strijd werd Troenodjojo eindelijk verslagen. De Nederlandse legeraanvoerder gaf de gouden kroon van Modjopahit, die Troenodjojo uit de kraton had meegenomen, aan de soesoehoenan. Een jaar later werd de rebel zelf gevangen genomen en door de soesoehoenan gedood. Deze laatste vestigde zich in 1680 in een nieuwe kraton, Kartasoera. Daarnaast kwam een Nederlandse vesting met een VOC-detachement als 'lijfwacht' voor de vorst. Mataram was een vazalstaat van de VOC geworden.

De betrekkingen tussen de VOC en het sultanaat Bantam waren wisselvallig. De in 1628 gesloten vrede werd verschillende malen door oorlogen onderbroken. Niettemin wist Bantam zich goed te herstellen van de door de blokkade geleden schade en na het midden van de eeuw kwam het zelfs tot grote bloei onder het bewind van sultan Ageng. Het dreef handel met Arabië, Perzië, India, China en de Filippijnen en verleende gastvrijheid aan Britse, Deense en Franse kooplieden. Bantam werd niet alleen een concurrent van de VOC maar ook een militaire bedreiging, vooral toen het van het verval van Mataram gebruik maakte om zich meester te maken van Priangan ('de Preanger', het Soendanese bergland ten zuiden en zuidoosten van Batavia). Maar wederom werd een intern Indonesisch conflict de redding van de VOC. 
In 1680 werd sultan Ageng afgezet door een zoon, die later in de daarop gevolgde burgeroorlog de steun van de Compagnie inriep. Speelman, intussen gouverneur-generaal geworden, stelde daarvoor zware voorwaarden, die door de jonge sultan werden aanvaard. De troepen van de VOC versloegen daarop diens tegenstanders, waarbij ze diep het binnenland introkken en voor het eerst over land de zuidkust van Java bereikten. In 1683 gaf sultan Ageng zich over; hij eindigde zijn leven als gevangene in Batavia.

Ook het sultanaat Bantam werd nu een vazalstaat van de VOC. Omdat het gewest Tjirebon in diezelfde tijd eveneens haar opperheerschappij erkende, was voortaan heel West-Java onderhorig aan de Compagnie. De VOC bracht het dun bevolkte gebied van Priangan onder haar eigen bestuur. Een verder gevolg van de onderschikking van Bantam aan de Compagnie was, dat nu ook het aan Bantam onderhorige Lampong-gebied in het zuiden van Sumatra (een belangrijk produktiegebied van peper) onder VOC-heerschappij kwam. Als havenstad speelde Bantam geen grote rol meer. Alle niet tot de Compagnie behorende Europeanen moesten de stad verlaten. De Britten vestigden zich daarop in Benkoelen aan de westkust van Sumatra.

Bij het overlijden van Jan Pieterszoon Coen in 1629 waren Atjeh, Bantam, Mataram, Gowa en Ternate de vijf machtigste rijken van Indonesië. Toen Cornelis Speelman in 1684 stierf had Atjeh zijn macht verloren en waren de vier andere rijken onderhorig aan de VOC geworden.

\section{Het handelsrijk van de VOC}

Tegen het einde van de zeventiende eeuw was de Verenigde Oost-Indische Compagnie de grootste Europese macht in Azië. Portugal had daar alleen nog enige vestigingen aan de westkust van India, in Macao en op Timor (Hormoez had het al in het begin van de eeuw verloren). De Spaanse aanwezigheid beperkte zich tot de Filippijnen. De Britse EIC had haar vestigingen voornamelijk in India en Perzië. Zij beschikte sinds kort ook over publiekrechtelijke bevoegdheden naar het voorbeeld van de VOC en was vastbesloten daar gebruik van te maken; voorlopig echter lag zij nog ver achter bij de Nederlandse Compagnie. Intussen was op initiatief van de Franse regering ook een Franse Indië-maatschappij opgericht, maar deze bezat pas enkele vestigingen in India. Franse en Britse pogingen om vaste voet op Ceylon te krijgen waren door de strijdkrachten van de VOC verijdeld. Het Aziatische handelsrijk onder Nederlandse leiding was een feit geworden. De Compagnie bezat nu meer dan honderd handelsposten en andere vestigingen. Vele daarvan waren door forten versterkt.

Het meest westelijk lag de Kaapkolonie, in 1652 aan de zuidpunt van Afrika gesticht als pleisterplaats waar de VOC-schepen verse groente en vlees 


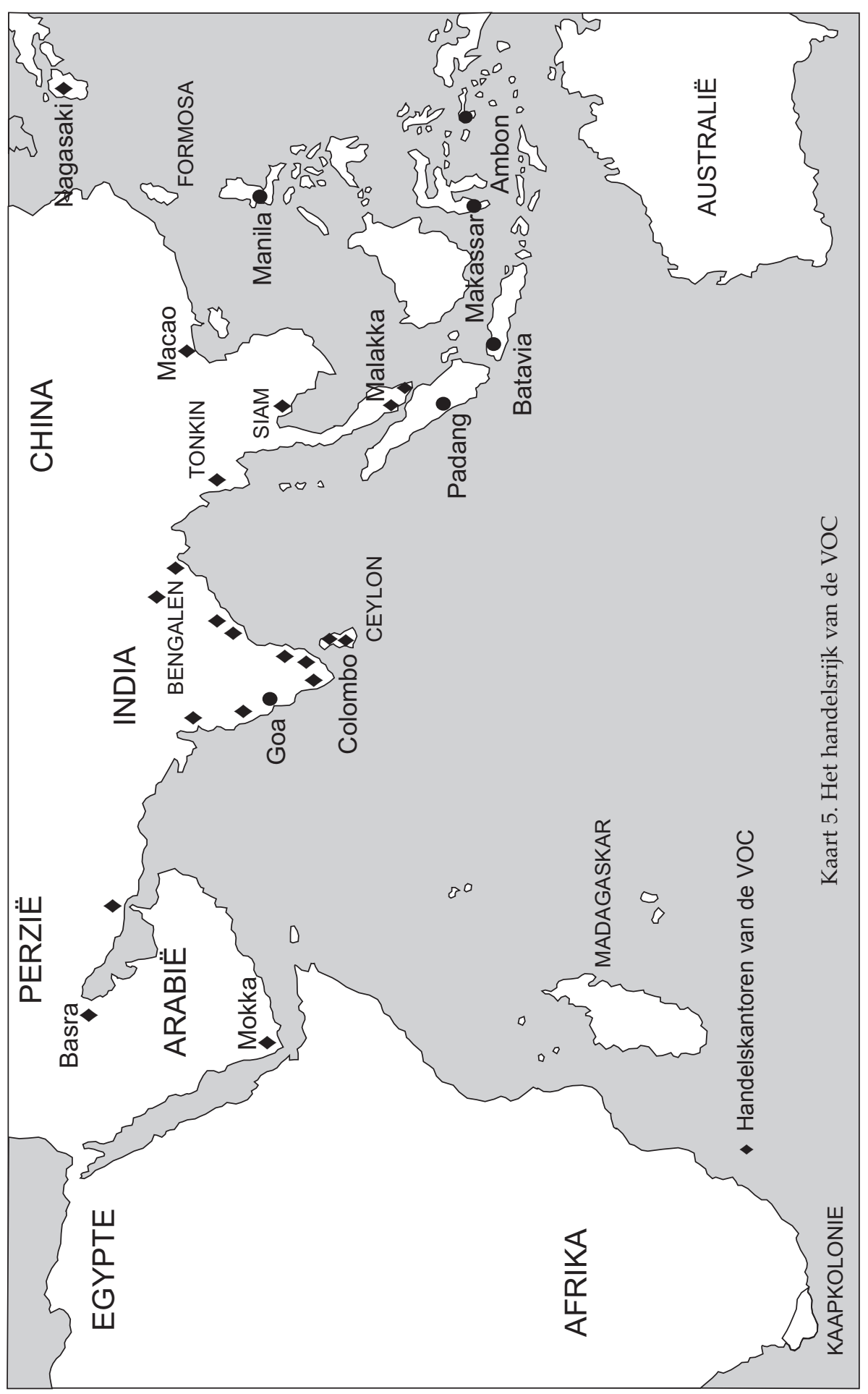


konden inslaan en reparaties ondergaan. Het was het enige gebied waar de Compagnie doelbewust een volksplanting stichtte. Zij hielp Nederlanders maar ook protestantse Duitsers en Fransen om zich daar als boeren te vestigen; Britten waren hiervan uitgesloten.

De meest westelijke plaatsen in Azië zelf waar de Compagnie ooit vestigingen bezat waren Mokka aan de Rode Zee en Basra aan de Perzische Golf. Daarnaast waren er ruim twintig VOC-posten langs de kusten van Perzië en India en ook verscheidene in het Perzische en Indiase binnenland. Op Ceylon beheerste de VOC Colombo en alle andere kuststeden. Wat Achter-Indië betreft, had zij handelsposten in Siam (Thailand) en Tonkin en aan de westkust en de oostkust van het schiereiland Malakka. Ten zuiden en zuidoosten daarvan beheerste zij een groot deel van de Indonesische archipel.

Daarentegen bezat de VOC lange tijd geen vestigingen in China. Zij had het daar verbruid door pogingen om zich met geweld toegang tot de Chinese markt te verschaffen. Weliswaar had zij zich in 1624 op Formosa (Taiwan) gevestigd, maar daar was zij in 1662 uit verdreven door Chinese tegenstanders van de Mantsjoe-dynastie; twintig jaar later had China zelf Formosa in bezit genomen. Overigens voerde de Compagnie wel degelijk handel met China, maar het transport tussen dat land en Batavia gebeurde meestal met Chinese schepen.

Terwijl de VOC in China geen posten mocht hebben, was haar verstandhouding met Japan uitgesproken goed. Al in 1609 had zij daar een handelskantoor kunnen openen. In de eerste decennia daarna nam zij veel Japanse huursoldaten in dienst. Toen de Japanse regering in 1636 besloot het land voor Europeanen te sluiten, mocht alleen de VOC daar een handelspost handhaven. Deze meest oostelijke VOC-post, gevestigd op het eilandje Desjima in de haven van Nagasaki, was meer dan twee eeuwen de enige verbinding van Japan met de westerse wereld.

De Compagnie had een groot aandeel verworven in de handel tussen de Aziatische landen. Met haar schepen zorgde zij voor de uitwisseling van bijvoorbeeld koffie uit Arabië, goud en edelstenen uit Perzië, katoenen weefsels, indigo, salpeter en opium uit India, kaneel en olifanten uit Ceylon, tin van het schiereiland Malakka, peper uit Sumatra, rijst en suiker uit Java, kruidnagelen, muskaatnoot en foelie uit de Molukken, zijde, porselein en thee uit China en zilver, koper en lakwerk uit Japan. De VOC-invoer uit Europa omvatte slechts een beperkt warenpakket, waaronder spiegelglas en wollen stoffen, en bestond verder voornamelijk uit zilveren munten. De uit Nederland komende schepen waren dan ook gedeeltelijk met ballast geladen, onder meer met bakstenen. De uitvoer van de Compagnie naar Europa bestond merendeels uit specerijen en textiel.

Bijna alle voor Europa bestemde waren werden eerst naar Batavia gebracht en daar opgeslagen in de centrale pakhuizen van de Compagnie, in afwachting 
van het transport met de retourvloten, die twee maal per jaar naar Nederland vertrokken. Voor het onderhoud van haar schepen beschikte de Compagnie over grote scheepswerven op het voor de kust gelegen eilandje Onrust. De VOC-schepen deden meestal een maand of zeven over de reis naar Nederland en acht of negen maanden over de reis van Nederland naar Batavia, maar volbrachten die reizen soms ook binnen een half jaar.

In het handelsbeleid van de VOC nam de verkrijging van monopolies een grote plaats in. Het ging daarbij zowel om exclusieve inkooprechten als om exclusieve verkooprechten. Toen bijvoorbeeld in 1677 de soesoehoenan van Mataram hulp vroeg om op zijn troon terug te keren, bedong de Compagnie daarvoor onder meer een exclusief recht op de invoer van katoenen weefsels en opium in zijn rijk. De verkoop van opium was één van de belangrijkste inkomstenbronnen van de VOC; zij heeft het gebruik daarvan dan ook sterk bevorderd.

De Compagnie werkte niet alleen met exclusieve inkooprechten, maar legde aan sommige gebieden ook verplichtingen tot levering op, hetzij tegen door haar vastgestelde prijzen hetzij als een soort van belastingen. Zulke gedwongen leveranties vormden een steeds belangrijker grondslag voor haar verwerving van handelswaren. Overigens beschikte zij over monopolies en leverdwang voornamelijk in Indonesië en op Ceylon. Daarbuiten, zoals in India, moest zij haar waren meestal op de vrije markt inkopen.

De kracht van de VOC kwam voor een deel voort uit haar strakke organisatie en haar unieke beschikking over kennis. Zij kon de prijzen en de kwaliteiten van waren op ver van elkaar gelegen markten vergelijken. Al haar posten moesten geregeld gedetailleerde rapporten aan het hoofdkwartier in Batavia opzenden, die daar werden verwerkt in de centrale boekhouding. Ook aardrijkskundige en zeevaartkundige gegevens werden door de Compagnie centraal verwerkt en bewaard. Op basis hiervan kregen haar scheepskapiteins kaarten uitgereikt die ze na afloop van hun reis weer moesten inleveren. Het hogere personeel werd binnen het handelsrijk veelvuldig overgeplaatst van de ene post naar de andere. Van de gouverneurs-generaal bijvoorbeeld zijn er vier in hun eerdere loopbaan hoofd geweest van het kantoor in Japan, vier gouverneur van Ceylon en vier gouverneur van de vestigingen aan India's oostkust.

De VOC was destijds de grootste particuliere onderneming ter wereld. Tegen het eind van de zeventiende eeuw had zij in Azië ongeveer 25.000 personen in dienst (van wie meer dan de helft militairen). Ruim 4000 hiervan behoorden tot het hoofdkwartier in Batavia. In en rondom de stad woonden toen ongeveer 70.000 mensen. Daarvan waren er een 6000 van Europese afkomst. Veel talrijker waren de Chinezen; verder waren er onder meer Portugees-sprekende immigranten uit Malakka en India naast Balinezen, Boeginezen, Javanen, Makassaren, Maleiers en Molukkers. De bevolking 
bestond voor meer dan de helft uit slaven. In de begintijd was Batavia een stad zonder achterland geweest, die over zee werd bevoorraad. Naderhand werd in de omtrek wel enige landbouw bedreven, maar pas in de laatste decennia van de eeuw, toen Bantam geen bedreiging meer vormde, begon men op grotere schaal het omliggende land in gebruik te nemen.

\section{Het bestuursstelsel van de VOC}

De Compagnie was een particuliere onderneming waaraan het recht verleend was overheidsfuncties uit te oefenen. $\mathrm{Zij}$ was geen staat, maar trad overzee wel op als een staat. Haar centraal bestuur overzee, bestaande uit de gouverneurgeneraal en de Raad van Indië, werd dan ook in de officiële instructies van de VOC aangeduid als de 'Hoge Regering'. Naast de gouverneur-generaal zelf telde de Raad aanvankelijk vier, maar uiteindelijk negen leden; de individuele leden werden eveneens Raad van Indië genoemd.

Het optreden van de VOC als een de facto staat hield onder meer in dat zij meende het recht te hebben over bepaalde gebieden het oppergezag uit te oefenen. Wat de grondslag van dat recht betreft volgde zij geen vaste lijn. In sommige gevallen gaf zij te kennen op te treden namens de Staten-Generaal, zodat de soevereiniteit over die gebieden eigenlijk bij Nederland zou berusten, terwijl zij in andere gevallen zichzelf als de soeverein presenteerde. In feite had het door de Staten-Generaal verleende octrooi de VOC niet uitdrukkelijk gemachtigd tot het verwerven van soevereiniteit over grondgebied, noch voor Nederland noch voor zichzelf. Niettemin achtte de Compagnie zich hiertoe bevoegd sinds het Portugese fort op Ambon zich in 1605 aan haar had overgegeven. De Staten-Generaal aanvaardden dat de VOC deze ruime uitleg aan haar mandaat gaf, maar verdiepten zich niet in de soevereiniteitskwestie. Zij namen zelfs geen kennis van de verdragen over de verwerving van grondgebied die de VOC met Aziatische vorsten sloot. Gelet op deze passieve houding van de Staten-Generaal zullen alle gebieden waarover de Compagnie het oppergezag uitoefende hier verder worden aangeduid als 'eigen grondgebied' van de VOC.

Wat betreft de uitoefening van overheidsfuncties door of namens de Hoge Regering in Batavia kan men verschillende categorieën van gebieden onderscheiden. Daarbij is het in de eerste plaats relevant of de VOC een gebied wel of niet als eigen grondgebied beschouwde. Ging het om eigen grondgebied, dan is het vervolgens van belang of de VOC dit gebied wel of niet onder haar rechtstreeks bestuur plaatste.

Aldus vallen als eerste categorie de gebieden te onderscheiden die de VOC als eigen grondgebied beschouwde en rechtstreeks bestuurde. Dit waren in hoofdzaak gebieden waarover de VOC meende het oppergezag te bezitten 
krachtens het recht van 'verovering in een rechtvaardige oorlog' (uiteraard vond de VOC alle door haar gepleegde oorlogshandelingen rechtvaardig). Bij het einde van de zeventiende eeuw was dit nog steeds een zeer beperkte categorie. Binnen Indonesië was het grootste van deze gebieden het deel van WestJava tussen de gewesten Bantam en Tjirebon; de VOC strekte daarbij haar souvereiniteitsaanspraken uit van Batavia tot Priangan en de zuidkust. Verder behoorden tot deze categorie alleen Ambon, de Banda-eilanden en de stad Makassar. Buiten Indonesië omvatte deze categorie de stad Malakka, de op Portugal veroverde steden in India en op Ceylon en tenslotte de Kaapkolonie. In de achttiende eeuw werd het rechtstreeks bestuurde gebied op Java sterk uitgebreid.

Een tweede categorie wordt gevormd door de gebieden die de VOC wel als eigen grondgebied beschouwde maar niet zelf bestuurde. In de regel waren dit gebieden die door inheemse vorsten aan de VOC waren overgedragen maar vervolgens door de VOC weer aan die vorsten 'in leen' waren gegeven. Het oppergezag berustte dan bij de VOC, maar deze liet het bestuur aan de vorsten over. Deze zwakkere vorm van souvereiniteit werd meestal 'suzereiniteit' genoemd. De gebieden placht men aan te duiden als 'leenroerige rijken'. Bij het einde van de zeventiende eeuw waren de sultanaten Ternate en Tidore de belangrijkste gebieden uit deze categorie; in de achttiende eeuw kwamen ook Bantam, Mataram en Madoera er onder te vallen.

In de derde plaats waren er gebieden die formeel souverein waren gebleven, maar in feite door verdragen en andere regelingen ondergeschikt waren geworden aan de Compagnie. Dit waren bijvoorbeeld verdragen waarin 'eeuwige trouw' aan de VOC was beloofd of permanente bescherming van de VOC was aanvaard. Soms werd in zulke verdragen de fictie gehandhaafd van een bondgenootschap op voet van gelijkheid. Tot deze derde categorie behoorden aan het einde van de zeventiende eeuw verscheidene gebieden op Celebes, Java en Sumatra en ook het koninkrijk Kandy op Ceylon. Men duidde zulke gebieden aan als 'bondgenootschappelijke rijken'. Hun eigen speelruimte verschilde van geval tot geval; meestal waren het niet meer dan vazalstaten. Overigens was het onderscheid tussen leenroerige en bondgenootschappelijke rijken in de praktijk niet altijd duidelijk. De bepalingen van de door de VOC gesloten verdragen leenden zich soms voor verschillende uitleg; bovendien werden die verdragen altijd in meer dan één taal opgesteld en kwam het voor dat de Nederlandse tekst afweek van de anderstalige tekst.

Naast deze drie categorieën kan men als vierde categorie de plaatsen onderscheiden waar de VOC wel handelsposten bezat, maar zelf volledig ondergeschikt was aan de autoriteiten van het land. Dit gold onder meer voor de VOC-posten in Perzië, in het Indiase rijk van de Groot-Mogols en in Japan.

Over deze vier categorieën van gebieden had de Compagnie één hiërar- 
chisch netwerk van ambtenaren uitgespreid. De top daarvan werd gevormd door de Hoge Regering in Batavia. Onmiddellijk daaronder ressorteerden de gouverneurs. Een stap lager in de hiërarchie stonden de plaatselijke vertegenwoordigers die als 'residenten' werden betiteld. In eerste aanleg was dit ambtelijk apparaat niet gevormd om gebied te besturen maar om handel te drijven, maar langzamerhand nam het bestuurswerk een steeds belangrijker plaats in. Niettemin bleven sommige VOC-ambtenaren, zelfs op het niveau van de gouverneurs en residenten, zich in hoofdzaak met commerciële en diplomatieke activiteiten bezighouden, bijvoorbeeld aan India's oostkust.

Het feit dat een gebied onder rechtstreeks bestuur van de Compagnie stond betekende overigens niet dat de hele bevolking rechtstreeks door VOCambtenaren bestuurd werd, zelfs niet in Batavia. Al in de begintijd was daar het dagelijks bewind over de Chinese bevolkingsgroep toevertrouwd aan een eigen 'kapitein der Chinezen', benoemd door de gouverneur-generaal. Later breidde men dit systeem ook uit tot andere etnische groepen in Batavia. Toen de VOC in het begin van de achttiende eeuw heel Priangan onder haar gezag bracht, liet zij de daar bestaande bestuursstructuur grotendeels intact. Daarbij profiteerde zij ervan dat hier, evenals in veel andere delen van Indonesië, een erfelijke ambtsadel bestond zonder vaste regels voor de opvolging. De Compagnie benoemde nu zelf uit deze adellijke families in de verschillende gewesten de hoogste inheemse bestuurders, door haar 'regenten' genoemd. Onder de regenten ressorteerden inheemse districts- en dorpshoofden. Dit inheemse bestuursnet stond onder oppertoezicht van de Compagnie. Wat de rechtspraak betreft, bepaalde de Hoge Regering dat alle strafzaken en burgerlijke zaken van de bevolking van Priangan berecht zouden worden door de regenten en de inheemse rechters op basis van het inheemse recht. De ambtenaren van de VOC zouden er alleen op moeten toezien dat onpartijdig recht gesproken werd. Ook in andere 'rechtstreeks bestuurde' gebieden handhaafde de Compagnie tot op zekere hoogte de inheemse rechts- en bestuursstelsels.

Omgekeerd maakte, in de gebieden die de VOC niet zelf bestuurde, het onderscheid tussen de tweede en de derde categorie (de leenroerige en de bondgenootschappelijke rijken) in de praktijk niet veel verschil. In beide gevallen berustte het bestuur bij de vorsten en andere inheemse gezagsdragers (eveneens vaak als 'regenten' aangeduid), maar in beide gevallen bevonden zich hoge VOC-ambtenaren (gouverneurs of residenten) in of nabij het gebied die controleerden of men zich wel hield aan de verplichtingen tegenover de Compagnie. Bovendien had de Compagnie er gewoonlijk eigen forten en garnizoenen. Ook in gebieden waarover de VOC niet soeverein was gedroeg zij zich soms als heer en meester, bijvoorbeeld binnen het sultanaat Ternate, waar zij al lang voordat dit gebied een 'leen' werd naar eigen goeddunken vruchtbomen vernielde en dorpen verbrandde.

Verder achtte de VOC zich ook bevoegd strafmaatregelen tegen politieke 
tegenstanders te nemen die ze buiten haar eigen grondgebied gevangen had genomen. Een veel toegepaste maatregel was interne verbanning; de ballingsoorden waren gewoonlijk gebieden van de eerste categorie. Zo heeft de VOC op Ceylon en in de Kaapkolonie een aanzienlijk aantal Indonesiërs geïnterneerd; in Zuid-Afrika is daar een aparte islamitische gemeenschap uit ontstaan.

\section{Indonesie als studieterrein en thuisland voor Compagniesdienaren}

Dienaren van de VOC deden soms nog andere dingen dan varen, handeldrijven, besturen en oorlog voeren. Sommigen publiceerden reisverhalen over hun eigen belevenissen, anderen schreven over de geschiedenis van de Compagnie. Deze geschriften bevatten natuurlijk allerlei gegevens over de vreemde landen en volkeren waarmee men in aanraking kwam, maar betroffen toch in de eerste plaats wat Nederlanders hadden beleefd en gedaan. Verschillende Compagniesdienaren ondernamen echter ook studies die zich rechtstreeks op die vreemde landen en volkeren richtten.

Hiertoe behoorde in de eerste plaats de studie van het Maleis en andere Aziatische talen, in het voetspoor van Frederik de Houtman die daar al voor de oprichting van de VOC mee begonnen was. De grootste talenkenner in VOC-dienst was Herbert de Jager, die van 1662 tot 1692 afwisselend in Batavia, Perzië en India gewerkt heeft. Hij kende Arabisch, Perzisch, Sanskriet, Tamil, Malgassisch, Maleis en Javaans en hield zich ook met vergelijkende taalkunde bezig. In de tweede plaats maakten verscheidene VOC-dienaren nauwkeurige beschrijvingen van de bevolking en de geografie van bepaalde gebieden. Enkelen verdiepten zich ook in de eigen geschiedenis van die gebieden voor de komst van de Nederlanders. Verdere voorwerpen van studie waren de godsdiensten, waaronder het hindoeïsme, en de inheemse rechtsstelsels, zoals de adat, het oude gewoonterecht. Tal van Compagniesdienaren waren gefascineerd door de tropische natuur. Meerderen van hen hielden zich met plantkunde bezig; één liet een twaalfdelige flora van India's westkust samenstellen die eeuwenlang als standaardwerk heeft gegolden.

De VOC nam zelf meermalen het initiatief voor geografische ontdekkingsreizen, zoals die in 1642 van Abel Tasman die heel Australië omzeilde, waarbij hij onder meer het eiland ontdekte dat later Tasmanië genoemd is en de eilandengroep die de naam Nieuw-Zeeland gekregen heeft.

De beroemdste geleerde onder de VOC-ambtenaren was de Duitser Georgius Rumphius, die in 1655 in Ambon geplaatst werd en daar tot zijn dood in 1702 is gebleven. Hij schreef veelomvattende boeken, onder meer over de geschiedenis van Ambon en over de plantenwereld, de schaal- en schelpdieren en de mineralen van de Molukken. Hij deed dit werk naast zijn 


\section{D'AMBOINSCHE RAR ITEITKAMER,}

Behelzende eene BESCHR Y VINGE van allerhande zoo weeke als harde

\section{SCHA A L V IS S C HE N,}

te weeten raare

KRABBEN, KREEFTEN,

en diergelyke Zeedieren, als mede allerbande

\section{HOORNTJES en SCHULPEN,}

die men in d'Amboinfche Zee vindt:

Daar beneven zommige

MINERAALEN, GESTEENTEN,

en foorten van AARDE, die in d'Amboinfche, en zom. mige omleggende Eilanden gevonden worden.

Verdeelt in drie Boeken,

En met nodige PRINTVERBEELDINGEN, alle naar 't leven getekent, voorzien.

Befchreven door

GEORGIUS EVERHARDUS RUMPHIUS,

van Hanauw, Koopman en Raad in Amboina, mitsgaders Lid in d'Academic Curioforum Natura s in 't Duitfche Roomfche Ryk opgerecht, onder den naam van PLINIUS IN DICUS.

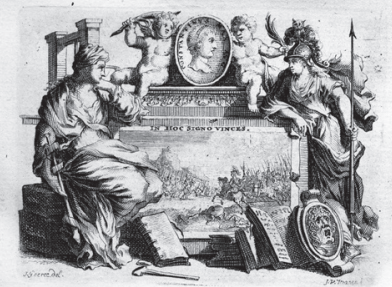

T'A M S T E R D A M,

Gedrukt by F R A N C O I S H A L M A, Boekverkoper in Konftantijn den Grooten.

1705 .

De in 1705 in druk verschenen Amboinsche Rariteitkamer, een rijk geillustreerde beschrijving van in de Molukken aangetroffen schaaldieren, schelpen en mineralen, was het laatste grote werk van de VOC-dienaar Georg Rumphius (1628-1702), die onder meer ook over de flora en de geschiedenis van Ambon heeft geschreven. 
bestuurstaken en werkte onvermoeibaar door hoewel hij blind werd en nog door andere rampen getroffen werd. De VOC-leiding in Batavia liet hem de vrijheid om dit werk te verrichten en zorgde soms voor assistentie.

Niet alleen toonden verschillende Compagniesdienaren door hun studies dat zij belang stelden in het land waar zij hun dienst verrichtten, maar ook bleken velen zich er thuis te voelen. Al sinds de begintijd keerden veel lagere Europese dienaren na hun diensttijd niet naar Europa terug, omdat zij inmiddels een inheemse levensgezellin gevonden hadden en omdat zij niet rijk genoeg waren om zich in hun vaderland een nieuw bestaan op te bouwen. Maar sinds de laatste decennia van de zeventiende eeuw bleven ook steeds meer hogere ambtenaren in Azië wonen, hoewel zij het zich financieel zeer wel konden veroorloven om hun leven in Europa voort te zetten. Dit gold onder andere voor verscheidene hoge VOC-functionarissen die landgoederen stichtten in de omgeving van Batavia en daar een grote staat voerden, naar het voorbeeld van de inheemse adel. Ook zeven gouverneurs-generaal gaven er de voorkeur aan in Indonesië te sterven nadat zij het ambt hadden neergelegd. Tegelijk nam onder de hoge Compagniesdienaren het aantal toe van hen die zelf niet in Europa maar in VOC-gebied geboren waren. Hiertoe behoorden ook vier gouverneurs-generaal (geboren in Ambon, Batavia, Ceylon en de Kaapkolonie). In het bijzonder Indonesië werd door velen beschouwd als het land waar men thuis was.

De eerste gouverneur-generaal die welbewust in Indonesië bleef wonen was Joannes Camphuys. Hij had zijn ambt vervuld van 1684 tot 1691 en bezat een kring van vrienden die een humaan beleid jegens de inheemse bevolking voorstonden. Ook de geleerden De Jager en Rumphius behoorden tot die kring, evenals Cornelis Chasteleyn, die onder meer een ethisch manifest schreef tegen de koopmanspolitiek van de VOC. Deze Chasteleyn stichtte drie landgoederen bij de hoofdstad. Eén daarvan was Weltevreden, waar later een nieuw deel van Batavia naar genoemd is; een ander was Depok, dat Chasteleyn bij zijn dood naliet aan zijn tot het christendom bekeerde slaven, waarna het tot in de twintigste eeuw als christengemeenschap is blijven bestaan. De vooruitstrevende denkbeelden van Camphuys en de zijnen hebben echter nauwelijks invloed gehad op het VOC-beleid in de achttiende eeuw.

\section{Invoering van de koffieteelt op Java}

Lange tijd bracht het gebied van Batavia zelf geen handelswaren voort. In de tweede helft van de zeventiende eeuw kwam hierin verandering toen Chinese ondernemers in de omstreken van de stad suikerrietplantages stichtten. De VOC zette de daar gewonnen suiker meestal in Azië af, omdat in Europa toen de rietsuiker uit West-Indië goedkoper was. Tegen het eind van de eeuw 
breidde deze Chinese suikerindustrie zich sterk uit.

Intussen begon in diezelfde tijd het koffiedrinken in Europa populair te worden en de Compagnie maakte goede winsten met de koffie die zij daar uit Arabië importeerde. Dit bracht enige leidende VOC-functionarissen op de gedachte te onderzoeken of koffie ook op Java geteeld zou kunnen worden. Hun gedachte had tot gevolg dat de VOC behalve een handelsonderneming ook een landbouwonderneming werd. Het in de eerste decennia van de achttiende eeuw ondernomen experiment had zoveel succes, dat Java al spoedig meer koffie voortbracht dan Arabië en dat de verkoop van koffie in het laatste kwart van de eeuw de voornaamste inkomstenbron van de VOC werd.

De Compagnie ondernam de koffieproductie niet zelf, maar verstrekte zaden en plantgoed aan de regenten in West-Java opdat zij hun onderdanen koffie zouden laten verbouwen. In het bergland van Priangan (de Preanger) bleek dit grote oogsten op te leveren. De Compagnie kocht de koffie van de regenten tegen een door haarzelf vastgestelde prijs en liet het aan hen over hoe zij de door hun boeren verrichte arbeid wilden vergoeden. De regenten verleenden vrijwillig hun medewerking aan de koffieteelt, maar de bevolking toonde hier na enige tijd weinig animo meer voor. Daarom ging de Compagnie over tot een minder vrijblijvend systeem. Zij kondigde een monopolie op koffie af en voerde een leveringsplicht in, zich baserend op haar soevereiniteit over het gebied. Evenals daar vroeger verplichtingen gegolden hadden tot de afdracht van rijst en dergelijke aan de soesoehoenan, werden de regenten voortaan verplicht koffie aan de VOC te leveren. Eerst bepaalde de Compagnie alleen de te leveren hoeveelheden, later stelde zij jaarlijks ook de aanplant van een bepaald aantal koffiebomen verplicht. Aan elke regent werd een VOC-controleur toegevoegd, de koffiesergeant, om te helpen bij het toezicht op de productie.

Dit regiem van gedwongen aanplant en levering werd later het Preangerstelsel genoemd. De regenten hadden groot persoonlijk belang bij het stelsel omdat de Compagnie niet aan de boeren maar aan hen voor de koffie betaalde. Zij vergrootten bovendien hun eigen afhankelijkheid van de Compagnie door voorschotten op die betalingen op te nemen; na enige tijd overtroffen hun schulden de waarde van de jaarlijkse koffieoogst.

\section{Chinees verzet en Chinezenmoord}

Chinezen speelden in Batavia een belangrijke rol als tussenhandelaren, winkeliers en ambachtslieden en werden door de VOC van begin af aan met voorkomendheid behandeld. Zij woonden evenals de Europeanen verspreid door de stad en niet in een afzonderlijke wijk buiten de stadswallen zoals de andere Aziatische bevolkingsgroepen. In het laatste deel van de zeventiende 
eeuw vestigden zich ook veel Chinezen in de omstreken, waar zij onder meer werkten in de landbouw en de suikerindustrie. Hun aantal overtrof na enige tijd dat van de Chinezen in Batavia en nam decennia lang verder toe door immigratie uit het Chinese moederland. Voor veel van deze immigranten was er echter geen emplooi, onder andere omdat de VOC de suikerproductie drastisch inperkte om de prijs hoog te houden. Intussen was ook de Nederlandse gemeenschap er niet goed aan toe. De bloeitijd van de VOC was voorbij, de welvaart ging achteruit en Batavia werd sinds 1732 geteisterd door een reeks epidemieën die veel slachtoffers eiste.

De werkloos rondzwervende Chinezen, die soms de omstreken van Batavia onveilig maakten, verontrustten de Hoge Regering steeds meer. Nadat verschillende pogingen tot beperking van de Chinese immigratie waren mislukt, besloot zij eind juli 1740 alle Chinezen zonder middelen van bestaan op te pakken. Men zou hen dan naar Ceylon of Zuid-Afrika kunnen deporteren. Onder de Chinezen verspreidde zich het gerucht dat men van plan was hen in zee te verdrinken. Een beperkt aantal Chinezen werd inderdaad opgepakt, velen vluchtten het binnenland in om zich aan deportatie te onttrekken, sommigen vormden gewapende strijdgroepen. Begin oktober vonden dicht bij Batavia enige gevechten plaats tussen zulke strijdgroepen en VOC-detachementen. $\mathrm{Na}$ een Chinese aanval op één van de stadspoorten brak op 9 oktober paniek uit onder de Nederlandse bevolking van Batavia, wat leidde tot een anti-Chinese pogrom. De ruim vierduizend Chinese inwoners van de stad werden in enkele dagen volledig uitgeroeid, hun bezittingen geplunderd, hun huizen verbrand. De Hoge Regering ondernam niets om deze moordpartij tegen te gaan.

Gedurende de maanden hierna werden nog eens duizenden Chinezen gedood bij militaire acties tegen de in West-Java rondzwervende groepen. De resterende strijdgroepen weken naar Midden-Java uit. Intussen nam de Hoge Regering wel verschillende maatregelen om het vertrouwen van de buiten Batavia verblijvende 'reguliere' Chinezen terug te winnen. Chinezen mochten echter voortaan niet meer in de binnenstad wonen. Zij kregen als woonoord een terrein buiten de stadswal toegewezen, waar later de wijk Glodok uit is ontstaan.

\section{Ondergang van Mataram}

Nadat het rijk Mataram door het verdrag van 1677 afhankelijk van de VOC was geworden, bleef het nog driekwart eeuw bestaan. Het werd in die tijd veelvuldig geteisterd door oorlogsgeweld. Dat kwam zowel door conflicten over de troonopvolging als door opstanden binnen het rijk, die zich ook tegen de VOC keerden.

In Mataram bestond geen vaste regel voor de opvolging van de vorst; zowel zoons als broers kwamen daarvoor in aanmerking. Vrijwel steeds wan- 
neer een soesoehoenan overleed, maakten verschillende leden van zijn familie aanspraak op de troon. Driemaal leidde dit tot een langdurige opvolgingsoorlog. Telkens steunde de VOC met haar strijdkrachten één van de rivalen en telkens liet zij zich voor die steun belonen met nieuwe concessies. Zo werden na de eerste opvolgingsoorlog in het begin van de achttiende eeuw alle districten van Mataram verplicht tot regelmatige leveranties aan de Compagnie. Bovendien werd Semarang toen definitief aan de VOC afgestaan; deze vestigde daar haar hoofdkwartier voor Midden- en Oost-Java en bouwde er een sterke vesting.

Veel Mataramse gezagsdragers ergerden zich aan de bevoogding van hun land door de VOC. Zij gaven daarom soms steun aan opstandige bewegingen die weliswaar het gezag van de soesoehoenan aantastten maar toch in de eerste plaats een bedreiging voor de Compagnie vormden. De eerste van die bewegingen werd geleid door Soeropati, een Balinees die officier in het VOC-leger geweest was. In 1686 overviel hij het Nederlandse garnizoen in Kartasoera; daarna trok hij met zijn aanhangers naar het Oost-Javaanse gebied van Pasoeroean, waar hij zich twintig jaar wist te handhaven. De tweede opstand begon in 1717 en richtte zich onder meer tegen de VOC-post in Soerabaja, die bijna een jaar lang werd belegerd. Nadat de VOC de belegeraars daar eindelijk had verslagen, overleed de soesoehoenan en brak een nieuwe opvolgingsoorlog uit. De Soerabajase rebellie ging op in deze oorlog, die vier jaar duurde.

De derde en voor de VOC gevaarlijkste rebellie brak in 1741 uit, als gevolg van het Nederlandse optreden tegen de Chinezen in en rondom Batavia. De naar Midden-Java uitgeweken Chinese strijdgroepen keerden zich samen met Javaanse strijders tegen de posten van de Compagnie. Zij slaagden er bijna in de VOC-vesting in Semarang te veroveren; pas tegen het eind van het jaar kon de Compagnie het beleg van de vesting doorbreken. Wat als Chinees verzet was begonnen werd intussen steeds meer een Javaanse opstand. In Kartasoera werd het VOC-garnizoen overmeesterd en het Nederlandse fort afgebroken. Een jaar later verdreven de rebellen ook de soesoehoenan uit Kartasoera en riepen zij een tegen-soesoehoenan uit. De VOC kon de rebellie uiteindelijk bedwingen dank zij de hulp van een Madoerese vorst. De door haar op zijn troon teruggebrachte soesoehoenan verplaatste zijn kraton naar een nieuwe residentie, Soerakarta aan de rivier de Solo. In 1743 sloot hij een verdrag met de VOC waarbij hij haar onder meer de hele noordkust van Midden- en Oost-Java afstond. De rijksbestuurders van Mataram moesten voortaan in Semarang een eed van trouw aan de Compagnie afleggen. Naast de nieuwe kraton bouwde de VOC een sterke vesting waarin een Nederlandse resident kwam te zetelen. Semarang werd de zetel van een gouverneur.

In 1749 stond de soesoehoenan op zijn sterfbed zijn hele rijk af aan de Compagnie en liet hij de beslissing over zijn opvolging aan haar over. Mataram 
werd daardoor in feite een leen van de VOC. Een deel van de Mataramse adel erkende deze daad niet als rechtsgeldig en riep in Jogjakarta de broer van de soesoehoenan tot zijn opvolger uit. Hierna begon een jarenlange opvolgingsoorlog tussen de zoon van de overledene, die door de VOC als opvolger werd aangewezen, en de in Jogjakarta ingehuldigde broer. De laatste had veel meer aanhang onder de Javaanse bevolking; de legers van de eerste en van de Compagnie bleken niet in staat hem een beslissende nederlaag toe te brengen. Overigens ontwikkelde de strijd zich tot een driehoeksoorlog, omdat nog een derde familielid aanspraak op de troon maakte. Tenslotte waren alle partijen zo verzwakt dat de VOC in 1755 een eind aan de strijd kon maken door een politieke oplossing. Er werden twee even grote vorstendommen gevormd: Soerakarta (ook wel Solo genoemd) onder de door de VOC aangewezen soesoehoenan en Jogjakarta onder zijn oom, die de titel van sultan kreeg. Bovendien werden ook enige gebieden toegewezen aan de derde pretendent, met de titel van 'mangkoenegara' en met zetel in Soerakarta. Deze deling betekende het eind van het rijk Mataram. In het vervolg moesten de soesoehoenan, de sultan en de mangkoenegara zelf trouw aan de Compagnie zweren. Ook Jogjakarta kreeg nu een VOC-resident en een VOC-garnizoen.

\section{Ontstaan van de Djojobojo-legende}

De Javaanse samenleving werd door de opvolgingsoorlogen ernstig ontwricht ten gevolge van de oorlogsmethodiek van de troonpretendenten. Meestal probeerden zij overwicht te krijgen door massale legers op de been te brengen. De recrutering daarvan beroofde de landbouw van het merendeel van haar arbeidskrachten. Bovendien richtte de oorlogvoering zich in sterke mate op vernietiging van de bestaansmiddelen van de tegenpartij. Grote delen van de bevolking werden getroffen door hongersnood. Sommige gebieden in OostJava werden door deze oorlogen geheel ontvolkt; later vestigden zich daar immigranten uit Madoera.

In het tijdvak van de ondergang van het rijk Mataram begonnen voorspellingen de ronde te doen die de Javaanse bevolking enige troost boden in haar ellende. Volgens de legende zouden die voorspellingen gedaan zijn door koning Djojobojo, de vorst van Kediri uit de twaalfde eeuw die het heldendicht Mahabharata voor de Javanen toegankelijk gemaakt had. Hij zou een toekomst geprofeteerd hebben waarin het volk door rampspoed zou worden getroffen, de vorsten verderfelijke bevelen zouden geven en het land in de macht zou komen van een zeevarend volk van overzee. Maar na verdere rampen en verwikkelingen zou er tenslotte redding komen in de persoon van een 'rechtvaardige vorst', een ratoe adil, die de vijanden zou verdrijven en een rijk van vrede en voorspoed zou vestigen. Deze aan Djojobojo toegeschreven 
profetie vertoont verwantschap zowel met islamitische heilsverwachtingen als met hindoeïstische voorstellingen over een afwisseling van slechte en goede tijden. De profetie werd in allerlei varianten doorgegeven; de kern ervan was steeds de verwachting van de verlossende ratoe adil, een verwachting die nog eeuwen lang zou voortleven.

\section{Achteruitgang van de VOC}

De VOC werd in de achttiende eeuw weliswaar steeds sterker als territoriale macht op Java, maar als handelsonderneming ging zij in diezelfde tijd achteruit omdat de verhouding tussen haar inkomsten en uitgaven zich ongunstig ontwikkelde.

De uitgaven van de VOC stegen in de achttiende eeuw onder meer als gevolg van haar talrijke militaire operaties. Dat waren in de eerste plaats de hierboven al vermelde operaties in Midden- en Oost-Java; daarnaast bood de VOC het hoofd aan grote opstanden in Bantam en op Ceylon en voerde zij jarenlang strijd tot onderwerping van het eiland Madoera en van het deel van Java ten oosten van Pasoeroean ('Java's Oosthoek').

De kostenstijging van de VOC weerspiegelde bovendien de groei van haar personeelsbestand in Azië, van ongeveer vijfentwintigduizend man burgerlijk en militair personeel in 1700 naar ongeveer vijfendertigduizend in 1750 . Deze groei had enerzijds zakelijke gronden, omdat de Compagnie zich steeds intensiever met bestuurswerk ging bezighouden, maar was anderzijds ook te wijten aan voortschrijdende bureaucratisering. Overigens was de salariëring van het Compagniespersoneel uitzonderlijk laag en bestond er geen recht op pensioen. De meeste Compagniesdienaren probeerden er dan ook wat bij te verdienen, bijvoorbeeld door zelf in monopoliewaren zoals opium te handelen. De hoogste VOC-functionarissen vergaarden dikwijls enorme persoonlijke rijkdommen, ten koste van de inheemse bevolking én ten koste van de Compagnie.

Evenals vroeger bij de Portugezen had nu bij de Nederlanders in Azië het oorspronkelijk elan plaats gemaakt voor corruptie en sleur. De boekhouding volgde nog steeds het systeem dat in het begin van de vorige eeuw was opgezet, de zeevaartkundige kennis werd niet vernieuwd, de bewapening van de schepen was verouderd, vestingwerken werden slecht onderhouden.

De wantoestanden bij de Compagnie in Azië verontrustten het VOCbestuur in Nederland zozeer, dat het in 1731 de gouverneur-generaal en enige andere hoge Compagniesdienaren ontsloeg en naar Nederland liet komen. Deze bijna wanhopige poging om orde op zaken te stellen kon het tij echter niet keren. Van de gouverneurs-generaal uit de achttiende eeuw heeft maar één geprobeerd de sleur te doorbreken. Dit was Gustaaf van Imhoff, die in 
1743 benoemd werd en die de Heren Zeventien al eerder voorstellen gedaan had om het verval tegen te gaan. Hij voerde in Batavia allerlei vernieuwingen in, bevorderde de uitgave van een krant (die prompt door het Nederlandse VOC-bestuur verboden werd), reisde door het land en bezocht de soesoehoenan in zijn kraton. Terwijl hij in 1740 als lid van de Raad van Indië het ongelukkige initiatief genomen had tot deportatie van de werkloze Chinezen, spande hij zich nu in om de positie van de Chinezen te verbeteren. Ten zuiden van Batavia liet hij aan de voet van de bergen het landhuis 'Buitenzorg' bouwen. Na zijn dood in 1750 was dit vrijwel het enige dat van zijn vernieuwingen in stand bleef.

Ook de belangstelling voor wetenschappelijk onderzoek ging in de achttiende eeuw achteruit, maar het eind van de eeuw bracht hier een kentering. In 1778 werd het Bataviaasch Genootschap van Kunsten en Letteren opgericht, dat zich onder meer ten doel stelde de studie van de geschiedenis en de gebruiken van de inheemse volkeren te bevorderen.

De achteruitgang van de Compagnie als handelsonderneming had verschillende facetten. In de eerste plaats waren de opbrengsten van de Aziatische handel al sinds het eind van de zeventiende eeuw niet meer voldoende om de apparaatskosten van de VOC in Azië volledig te dekken. Niet alleen stegen die kosten, maar ook ging de rentabiliteit van deze handel zelf achteruit. Verarming van de bevolking op Java bijvoorbeeld bemoeilijkte daar de afzet van Indiase textiel. Het Aziatisch handelsrijk van de Compagnie werd kleiner. Zij sloot haar kantoren in Arabië, Perzië, Siam en Tonkin. Het kantoor in Japan bleef gehandhaafd, maar werd een verliespost. In India verloor de VOC in de achttiende eeuw haar dominerende positie, toen enige belangrijke delen van dat land in de macht kwamen van de Britse en de Franse compagnie, die overigens ook elkaar bestreden. Daar stond tegenover dat de VOC nu eindelijk toestemming kreeg om op China te varen; in 1749 kon zij daar in Kanton een eigen handelspost openen.

Intussen ontleende de VOC haar inkomen in Azië niet alleen aan de Aziatische handel. Omdat zij zich op Java tot een territoriale macht ontwikkelde, werden hier ook andere inkomstenbronnen belangrijk, zoals belastingen en tolheffingen. Bovendien genoot zij onzichtbare inkomsten doordat zij veelvuldig gebruik maakte van 'herendiensten', onbetaalde arbeid van de inheemse bevolking, onder meer voor de aanleg van versterkingen en wegen. De inning van belastingen werd vaak aan Chinezen verpacht. Ook verhuurde de Compagnie soms in de kustgebieden, naar het voorbeeld van de Javaanse regenten, hele dorpen aan Chinese ondernemers, waarbij de bevolking dan verplicht was voor die huurders herendiensten te verrichten. Maar ondanks deze uitbreiding van de inkomstenbronnen van de VOC konden haar ontvangsten in Azië de uitgaven niet bijhouden.

Gedurende de achttiende eeuw bleef de VOC grote hoeveelheden Aziatische 
waren in Europa importeren, naast specerijen en textiel nu vooral koffie en thee. De opbrengst van de verkopen in Europa diende ten dele om de tekorten op de Aziatische begroting te dekken. Maar terwijl de hoeveelheden groot bleven, werden de winstmarges bij verkoop steeds kleiner. Men kon bijvoorbeeld de prijs van kruidnagelen en muskaatnoten niet meer kunstmatig hoog houden, omdat die nu ook in Britse en Franse gebieden geproduceerd werden. Herhaaldelijk eindigde een bedrijfsjaar met verlies voor de VOC als geheel. Het bestuur hield dit geheim om het vertrouwen van de aandeelhouders niet te verliezen. Het ging door met het uitkeren van forse dividenden; eerst sprak het daartoe de reserves aan en vervolgens sloot het zelfs leningen.

De Staten-Generaal maakten zich zorgen over de VOC en gaven daar van tijd tot tijd blijk van wanneer verlenging van het octrooi aan de orde kwam. Om meer greep op de gang van zaken te krijgen benoemden ze in 1749 prins Willem IV, sinds kort stadhouder van alle provincies, tot opperbewindhebber van de VOC. Hij kreeg onder meer het recht belangrijke benoemingen te doen op voordracht van de Heren Zeventien.

\section{Einde van de VOC}

Omstreeks 1780 had de VOC in Indonesië vrijwel geen bedreigingen uit de archipel zelf meer te duchten. Zij had intussen ook een eind gemaakt aan het hindoeïstische rijkje Balambangan in Java's Oosthoek, zodat Java en Madoera nu volledig aan haar macht onderworpen waren. De inheemse vorsten en regenten waren ingeschakeld bij het bestuur over de bevolking en bij de levering van de door de Compagnie verlangde producten en hadden persoonlijk belang bij handhaving van die rol. Aldus was de VOC in staat met een paar duizend Nederlanders een volk van miljoenen te overheersen. De bevolking van Oost-Java begon weer te groeien nu zij niet meer door oorlogvoering geteisterd werd. Ook de bevolking van Priangan nam toe, ondanks de druk van de gedwongen koffieteelt. Met de eilanden ten oosten van Java bemoeide de VOC zich nauwelijks. Bali en Lombok waren geheel onafhankelijk; op WestTimor had de VOC een steunpunt; op Flores en Oost-Timor bevonden zich nog Portugese vestigingen. In de Molukken was de Compagnie oppermachtig; nog steeds ondernam zij daar de jaarlijkse hongi-tochten. Op Celebes had zij twee steunpunten, Makassar en Menado; verder had zij verdragsbanden met een aantal vorstendommen op het eiland. Op Borneo stelden de sultanaten Bandjermasin in het zuiden en Pontianak in het westen zich juist in deze tijd onder gezag van de VOC. Op Sumatra bezat de Compagnie het Lamponggebied aan de zuidpunt en het gebied van Padang aan de westkust, terwijl zij een vestiging had in het sultanaat Palembang aan de oostkust en ook de aan Palembang onderhorige eilanden Bangka en Biliton beheerste. Het sultanaat 


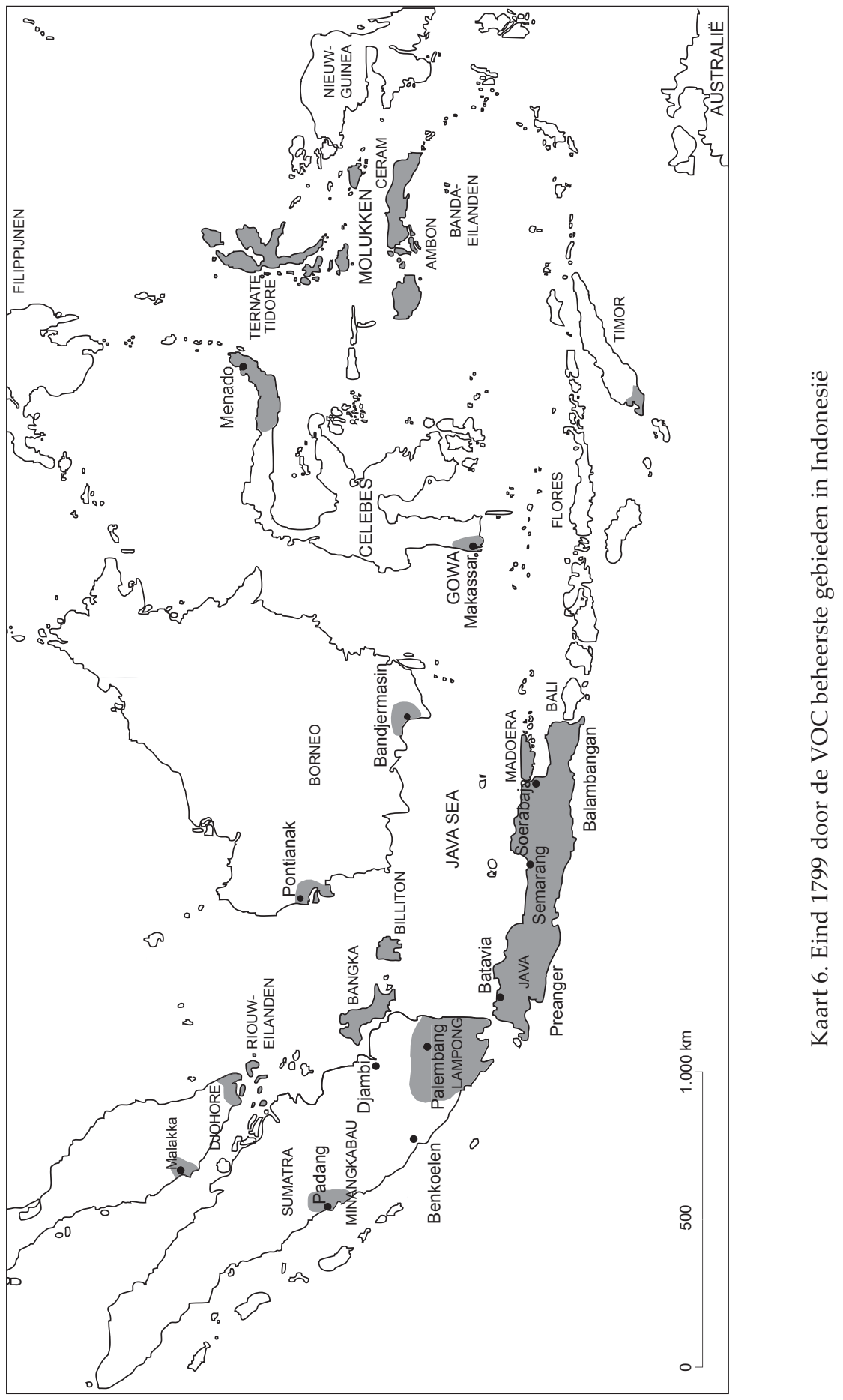


Atjeh was intussen als gevolg van een reeks opstanden en opvolgingsoorlogen uiteengevallen, al bleef de sultan in naam aan het hoofd staan.

Het enige Indonesische volk waarmee de VOC in deze tijd nog gewapende conflicten had was dat van de Boeginezen; niet in hun stamland Zuid-Celebes maar in het westen van de archipel. Zij beheersten onder meer de Riouweilanden en bedreigden de stad Malakka; in West-Borneo hadden zij een avonturier van Arabische afkomst geholpen bij de stichting van het sultanaat Pontianak; in Zuid-Borneo vielen zij Bandjermasin aan.

Inmiddels waren de Britten in India oppermachtig geworden door een definitieve overwinning op de Fransen. De VOC-posities in India en op Ceylon konden alleen nog gehandhaafd blijven voorzover ze door de EIC werden geduld. Bij een conflict in Bengalen was al gebleken dat de bewapende koopvaardijschepen van de VOC niet opgewassen waren tegen de Britse oorlogsschepen.

Aanvankelijk ontzag Groot-Brittannië de VOC, omdat het Nederland als een bondgenoot tegen Frankrijk beschouwde. In 1780 verklaarde het echter de oorlog aan de Republiek teneinde haar te beletten de voormalige Britse koloniën in Noord-Amerika te steunen die zich in 1776 onafhankelijk verklaard hadden. In Azië bezette de EIC nu enkele posten van de VOC, waaronder Padang. Ernstiger was dat zij het scheepvaartverkeer tussen Batavia en Nederland blokkeerde. In 1783 kwam er een wapenstilstand; in 1784 werd vrede gesloten. De VOC moest haar belangrijkste steunpunt in India opgeven, maar kreeg Padang terug; verder moest zij de Britten vrije vaart toestaan in de Indonesische archipel.

Deze Brits-Nederlandse oorlog gaf de Compagnie een klap waarvan zij zich niet meer hersteld heeft. Terwijl ze haar schuldenlast in de voorafgaande jaren juist had kunnen verkleinen, miste zij door de Britse blokkade drie jaar lang haar handelsinkomsten. Zij staakte nu de betaling van dividend en vroeg financiële steun aan de Staten-Generaal. Bovendien kreeg zij als gevolg van de oorlog een forse nieuwe schuld aan de Nederlandse staat. In 1783 had de Republiek namelijk een eskader van de Nederlandse marine naar Azië gestuurd, dat daar te laat aankwam voor de strijd tegen de Britten maar wel meehielp om de Boeginezen uit de Riouw-archipel te verdrijven. De Republiek bracht de kosten van dit eskader aan de Compagnie in rekening.

De Staten-Generaal vonden verdere financiële steun aan de VOC alleen verantwoord als ingrijpende veranderingen zouden worden doorgevoerd. Over de inhoud van die veranderingen kon men het echter niet eens worden als gevolg van de toen in de Republiek heersende politieke verdeeldheid. Tenslotte benoemde het VOC-bestuur zelf een commissie-generaal om het handels- en bestuurssysteem te reorganiseren. De voorzitter van die commissie, S.C. Nederburgh, nam in 1793 in Batavia het heft in handen en hield alle echte vernieuwing krachtdadig tegen. 
Externe factoren droegen ertoe bij dat toch over het lot van de Compagnie beslist werd. Enige jaren na de Franse Revolutie van 1789 raakte GrootBrittannië in oorlog met het revolutionaire Frankrijk. Onder invloed van de stadhouder prins Willem V sloot de Republiek zich daarbij aan. Maar in 1795 trok een Frans leger Nederland binnen, samen met een contingent Nederlandse revolutionairen, het Bataafs Legioen onder commando van Herman Willem Daendels. Willem V week naar Engeland uit en er kwam nu een eind aan de Republiek der Verenigde Nederlanden. Haar opvolgster, de Bataafse Republiek (de eerste Nederlandse eenheidsstaat), wilde de VOC niet langer als zelfstandige onderneming handhaven. Al in maart 1796 nam een door de regering ingesteld comité het bestuur van de Compagnie over. Vervolgens verlengde men het octrooi van de VOC nog één keer, tot eind 1799, en besloot men dat al haar activa en passiva zouden overgaan op de Nederlandse staat. Het personeel van de VOC overzee, onder wie de gouverneur-generaal, kwam in staatsdienst; de commissie-generaal werd ontbonden. Voorlopig zouden de Aziatische bezittingen nog worden beheerd volgens de inhoud van het laatste octrooi, totdat dit zou zijn vervangen door een nieuw 'Charter'.

Overigens was de feitelijke situatie overzee intussen ingrijpend gewijzigd. Omdat de Bataafse Republiek een Franse vazalstaat was, verkeerde zij van begin af aan in oorlog met Groot-Brittannië. Vanuit Engeland had Willem V als opperbewindhebber van de VOC aan al haar vestigingen opdracht gegeven zich tijdelijk onder Britse bescherming te stellen. In 1795 en 1796 werden de meeste VOC-vestigingen buiten Java door de EIC bezet. Op 31 december 1799 beschikte de VOC behalve over Java nog alleen over haar steunpunten in Palembang, Bandjermasin, Madoera, Makassar, Ternate en West-Timor en over haar handelskantoren in China en Japan.

Ondanks alle verdeeldheid in de laatste decennia van de achttiende eeuw over de vraag wat er met de VOC zou moeten gebeuren, is nooit gesproken over de mogelijkheid om de Nederlandse presentie in Azië eenvoudig op te geven. De overtuiging dat de Aziatische bezittingen onmisbaar voor de Nederlandse welvaart waren bleek onwrikbaar, ook al was de Compagnie in feite failliet. Haar schulden ten tijde van haar opheffing bedroegen 134 miljoen gulden.

\section{Aantekeningen bij hoofdstuk II}

\section{Literatuuroverzicht}

Van de literatuur over de geschiedenis van Indonesië gaat een groot deel over de koloniale tijd, het tijdvak van ruim drie eeuwen waarin Nederlanders zich in de Indonesische archipel vestigden en die bijna volledig onder hun macht brachten. Uiteraard wordt dit tijdvak behandeld in de al bij het vorige hoofdstuk vermelde 


\section{O U D en N I E U W OOST-INDIËN}

V E R V A T T E N D E

Een Naaukeurige en Uitvoerige Verhandelinge van $5=$ NEDERLANDS MOGENTHEYD

\section{In die

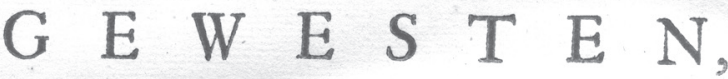

B E N E V E N S

Eene wydluftige Befchryvinge der MOLUCCOS, AMBOINA, BANDA, TIMOR, en SOLOR, JAVA, en alle de Eylanden onder dezelve Landbeftieringen behoorende; het Nederlands Comptoir op SURATTE, en de LEVENS DER GROOTE MOGOLS;

$$
\text { A L S OOK }
$$

Een Keurlyke Verhandeling van 't wezentlykfte, dat men behoort te weten van CHOROMANDEL, PEGU, ARRACAN, BENGALE, MOCHA, PERSIEN, MALACCA, SUMATRA, CEYLON, MALABAR, CELEBES of MACASSAR, CHINA,
JAPAN, TAYOUAN of FORMOSA, TONKIN, CAMBODIA, SIAM, APAN, TAYOUAN Of FORMOSA, TONKIN, CAMBODIA, SIAM
BORNEO, BALI, KAAP DER GOEDE HOOP en van MAURITIUS.

Te zamen dus behelzende niet alleen eene zeer nette Befchryving van alles, wat Nederlands Oofto Indiën betreft, madr ook 't voornaamfe dat eenigzins tot eenige andere Europeërs, in die Geweflen, betrekking beeft.

Met meer dan thien honderd en vyftig Prentverbeeldingen verrylkt.

Alles zeer naaukeurig, in opzigt van de Landen, Steden, Sterkten, Zeden der Volken, Boomen, Gewaffchen, Land- en Zec̀ - dieren, met alle het Wereldlyke en Kerkelyke, van d'Oudfte tyden af tot nu toe aldaar voorgevallen, befchreven, en met veele zeer nette daar toe vereyfchte Kaarten opgeheldert

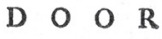

FRANCCOIS VALENTYN,

Onlangs Bedienaar des Goddelyken Woords in Amвогла, Banda, enz: I $\mathbb{N}$ Y Y E D E ELE $\mathbb{E}$.

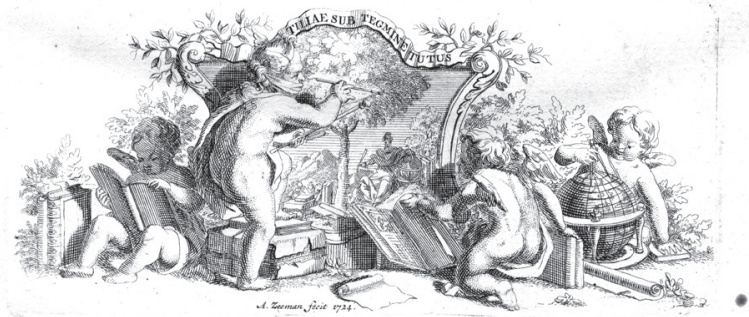

Te $\left\{\begin{array}{l}\text { DORDRRCRT, } \\ \text { AMSTERDAM, }\end{array}\right\}$ by $\left\{\begin{array}{l}\text { JOANERAS VAN BR A AM, } \\ \text { GERAR ONDER DE IINDEN, }\end{array}\right.$ A $D$ C $C X X \pi$ X

MET PRIVILEGIE

François Valentyn (1666-1727), die de VOC vele jaren als predikant had gediend, schreef na terugkeer in Nederland het standaardwerk Oud en Nieuw Oost-Indiën waarin hij alle vestigingen van de VOC behandelde. Het werk verscheen in

1724-26 in vijf delen met meer dan duizend afbeeldingen en kaarten. 
algemene werken, zoals de in 1938-1940 in vijf delen gepubliceerde Geschiedenis van Nederlandsch-Indië onder redactie van F.W. Stapel. Over het koloniale tijdvak was in 1925-1926 een meer specifiek overzicht in drie delen verschenen van de hand van H.T. Colenbrander: Koloniale geschiedenis. Dit werk bestreek enerzijds veel meer omdat het ook de koloniën van andere landen behandelde en ook de Nederlandse koloniën in Afrika en Amerika, anderzijds veel minder omdat het de koloniale geschiedenis van Indonesië beknopter en de prekoloniale geschiedenis in het geheel niet weergaf.

De koloniale geschiedenis van Indonesië valt ruwweg in twee periodes uiteen: die van de zeventiende en de achttiende eeuw, waarin de Verenigde Oost-Indische Compagnie zich in de Indonesische archipel vestigde, en die van de negentiende en een deel van de twintigste eeuw, waarin deze archipel grotendeels een kolonie van de Nederlandse staat vormde. De eerste periode is het onderwerp van dit hoofdstuk. Deze periode is al vroeg het voorwerp van belangrijke bronnenpublicaties geweest. Onder redactie van J.K.J. de Jonge begon in 1862 een publicatie van archiefstukken onder de titel De opkomst van het Nederlandsch gezag in Oost-Indië. Voortgezet onder redactie van M.L. van Deventer werd dit uiteindelijk een serie van tien delen die het tijdvak 1595-1811 bestreken. Vervolgens begon in 1907 onder redactie van J.R. Heeres een publicatie van in Azië gesloten verdragen onder de titel Corpus diplomaticum Neerlando-Indicum. Voortgezet onder redactie van F.W. Stapel werden dit uiteindelijk zes delen die het tijdvak 1596-1799 bestreken. Daarnaast bestaan er nog verscheidene andere seriepublicaties van documenten uit de archieven van de VOC.

De eerste geschiedwerken over de VOC zijn al tijdens het VOC-tijdperk geschreven. De belangrijkste hiervan zijn Beschryvinge van de Oostindische Compagnie door Pieter van Dam (zeven delen, voltooid in 1701) en Oud en nieuw Oost-Indiën door François Valentyn (vijf delen, gepubliceerd in 1724-1726).

Ook nadat Indonesië onafhankelijk geworden was, bleven Nederlandse en andere historici zich met de koloniale geschiedenis bezighouden. Zo verscheen in 1965 The Dutch seaborne empire van de Britse historicus C.R. Boxer. In 1982 publiceerde F.S. Gaastra De geschiedenis van de VOC (later in een uitgebreide versie herdrukt). Van de hand van J. van Goor verscheen in 1994 De Nederlandse koloniën; Geschiedenis van de Nederlandse expansie 1600-1975. In 1998 zag een nog ambitieuzer werk het licht: De waaier van het fortuin; Van handelscompagnie tot koloniaal imperium; De Nederlanders in Azië en de Indonesische archipel 1595-1950 door J.J.P. de Jong. De genoemde werken van Gaastra en J.J.P. de Jong gaan ook uitvoerig in op de economische aspecten (die in dit boek slechts summier aan de orde komen). In 2002 werd in Nederland herdacht dat vier eeuwen eerder de VOC opgericht was. Dit leidde ook tot verschillende publicaties, waaronder de bundel De Verenigde Oost-Indische Compagnie tussen oorlog en diplomatie onder redactie van Gerrit Knaap en Ger Teitler.

Evenals het vorige hoofdstuk is ook dit hoofdstuk in hoofdzaak gebaseerd op de daar al genoemde werken van De Graaf, Stapel en Vlekke. Hieronder volgen enige aanvullende opmerkingen en verwijzingen bij sommige paragrafen.

Oprichting van de Verenigde Oost-Indische Compagnie

Voor het door de Staten-Generaal aan de VOC gegeven octrooi zie Valentyn 2002, I:186-91. Artikel xxxv van dit octrooi bevat de machtiging tot uitoefening van overheidsfuncties. 


\section{Nederlaag van de Britten; stichting van Batavia}

Zoals blijkt uit Mijer 1848:14-5 heeft het VOC-bestuur al in 1609 opdracht gegeven aan gouverneur-generaal Both om te proberen in Djakarta een centraal rendez-vous te stichten dat geheel onder gezag van de Compagnie zou staan.

Over de herkomst en de betekenis van de naam Batavia bestaat veel verwarring. Zo vindt men in de literatuur soms dat die naam van Coen afkomstig was en soms dat de naam door een commandant van het VOC-fort bij Djakarta bedacht was. In werkelijkheid voerde die commandant slechts een besluit van het VOC-bestuur uit, terwijl Coen het hiermee oneens was en jarenlang weigerde de naam Batavia te gebruiken. Verder menen sommigen dat die naam naar het gewest Holland verwees.

De naam Batavia verwees echter naar een destijds in de Republiek gangbare vergelijking van de Nederlandse opstand tegen Spanje met een opstand uit het jaar 69 van de Bataven (een Germaanse stam die toen in de Rijndelta woonde) tegen de Romeinen. De naam doelde dan ook op het hele gebied van de Republiek (zie De Haan 1922, I:10-1).

Het besluit van de VOC over de naam van haar in Azië te stichten hoofdzetel dateerde al van 1617. De Heren Zeventien hadden in oktober van dat jaar tijdens een vergadering in Middelburg besloten dat het centrale rendez-vous Batavia zou moeten heten (zie De Jonge 1862-1909, IV:cxxxvii, noot 2).

Tijdens de belegering van het VOC-fort bij Djakarta gaf de leiding van het fort (in afwezigheid van Coen) uitvoering hieraan door dit fort op 12 maart 1619 de naam Batavia te geven. Tegelijk gaf zij aan de vier versterkte hoeken ervan de volgende namen: West-Vriesland, Geldria, Zeelandia en Hollandia (zie Valentyn 2002: deel IV, boek zes 'Batavia's grondvesting').

Dat de naam Batavia naar niets meer of minder dan Nederland zelf verwees, lijkt volledig in het vergeetboek te zijn geraakt. Mij is behalve Vlekke (1947:151) geen enkel sinds 1945 verschenen werk bekend dat hiervan rept.

De doelstellingen van de VOC

Vergelijk J.J.P. de Jong 1998:49-52.

Ontvolking van de Banda-eilanden

Vergelijk Van der Chijs 1886. Zie voor de destijds in Nederland geuite kritiek ook Vlekke 1947:153-5 en Vanvugt 1996:30-2.

Onderwerping van de Molukken

Zie Verwijnen 1902, Rumphius 1910 en Knaap 1987:25-34.

Het handelsrijk van de VOC

Vergelijk J.J.P. de Jong 1998:87-92. Over de opiumhandel zie Vanvugt 1985:53-99.

Het bestuursstelsel van de VOC

Zie ‘Contracten met zelfbesturende landschappen' in Encyclopaedie 1917:525-6, Kleintjes 1903:1-9, Van Kan 1942 en Somers 2001.

Indonesië als studieterrein en thuisland voor Compagniesdienaren

Vergelijk J.J.P. de Jong 1998:109-10, 118-20. 
Invoering van de koffieteelt op Java

Zie Vlekke 1947:221-9 en J.J.P. de Jong 1998:107-14.

Chinees verzet en Chinezenmoord

Zie J.Th. Vermeulen 1938; vergelijk Remmelink 1994:125-7, 134-7. Zie over de positie van de Chinezen Blussé 1986, over de epidemieën in Batavia Van der Brug 1994.

Ondergang van Mataram

Vergelijk Remmelink 1994:137-204 en Nagtegaal 1996.

Ontstaan van de Djojobojo-legende

Zie Wiselius 1872:204-5.

Achteruitgang van de VOC

Zie onder meer Van der Brug 1994 en Dillo 1992. Over het Bataviaasch Genootschap zie Groot 2007.

Einde van de VOC

Zie ook Schutte 1974 en Steur 1984. 